\title{
Review \\ Oxidative Stress, Inflammation and Connexin Hemichannels in Muscular Dystrophies
}

\author{
Arlek González-Jamett 1,2,*iD, Walter Vásquez ${ }^{1}$, Gabriela Cifuentes-Riveros ${ }^{2}$, Rafaela Martínez-Pando ${ }^{2}$, \\ Juan C. Sáez ${ }^{1}$ and Ana M. Cárdenas ${ }^{1, *(\mathbb{D})}$
}

1 Centro Interdisciplinario de Neurociencia de Valparaíso, Facultad de Ciencias, Universidad de Valparaíso, Valparaíso 2360102, Chile; wavasqueza@gmail.com (W.V.); juancarlos.saez@uv.cl (J.C.S.)

2 Escuela de Química y Farmacia, Facultad de Farmacia, Universidad de Valparaíso, Valparaíso 2360102, Chile; gabriela.cifuentes@alumnos.uv.cl (G.C.-R.); rafaela.martinez@alumnos.uv.cl (R.M.-P.)

* Correspondence: arlek.gonzalez@uv.cl (A.G.-J.); ana.cardenas@uv.cl (A.M.C.)

check for

updates

Citation: González-Jamett, A.;

Vásquez, W.; Cifuentes-Riveros, G.; Martínez-Pando, R.; Sáez, J.C.; Cárdenas, A.M. Oxidative Stress, Inflammation and Connexin

Hemichannels in Muscular Dystrophies. Biomedicines 2022, 10, 507. https://doi.org/10.3390/ biomedicines 10020507

Academic Editor: Juan Gambini

Received: 31 January 2022

Accepted: 15 February 2022

Published: 21 February 2022

Publisher's Note: MDPI stays neutral with regard to jurisdictional claims in published maps and institutional affiliations.

Copyright: (c) 2022 by the authors. Licensee MDPI, Basel, Switzerland. This article is an open access article distributed under the terms and conditions of the Creative Commons Attribution (CC BY) license (https:/ / creativecommons.org/licenses/by/ $4.0 /)$.

\begin{abstract}
Muscular dystrophies (MDs) are a heterogeneous group of congenital neuromuscular disorders whose clinical signs include myalgia, skeletal muscle weakness, hypotonia, and atrophy that leads to progressive muscle disability and loss of ambulation. MDs can also affect cardiac and respiratory muscles, impairing life-expectancy. MDs in clude Duchenne muscular dystrophy, Emery-Dreifuss muscular dystrophy, facioscapulohumeral muscular dystrophy and limb-girdle muscular dystrophy. These and other MDs are caused by mutations in genes that encode proteins responsible for the structure and function of skeletal muscles, such as components of the dystrophinglycoprotein-complex that connect the sarcomeric-actin with the extracellular matrix, allowing contractile force transmission and providing stability during muscle contraction. Consequently, in dystrophic conditions in which such proteins are affected, muscle integrity is disrupted, leading to local inflammatory responses, oxidative stress, $\mathrm{Ca}^{2+}$-dyshomeostasis and muscle degeneration. In this scenario, dysregulation of connexin hemichannels seem to be an early disruptor of the homeostasis that further plays a relevant role in these processes. The interaction between all these elements constitutes a positive feedback loop that contributes to the worsening of the diseases. Thus, we discuss here the interplay between inflammation, oxidative stress and connexin hemichannels in the progression of MDs and their potential as therapeutic targets.
\end{abstract}

Keywords: muscular dystrophies; inflammation; oxidative stress; connexin hemichannels; resveratrol

\section{Introduction}

Muscular dystrophies (MDs) are a heterogeneous group of diseases caused by mutations in genes encoding proteins with key functions for the muscle integrity. Despite their diverse genetic causes, MDs exhibit common clinical features that include progressive weakness and atrophy of specific muscular groups, e.g., distal limb, face, shoulder or upper arm and leg skeletal muscle, joint contractures, loss of ambulation, and respiratory and swallowing difficulties as the diseases progress [1]. Some MDs are also associated with cardiac disorders [2]. MDs' aspects, such as their onset, severity, muscles affected, and rate of progression, mostly depend on the mutated gene. In this regard, mutations in around 50 genes have been associated with at least 70 different types of MD, which have been classified in nine different categories (see Table 1): Becker muscular dystrophy (BMD), congenital muscular dystrophy (CMD), distal muscular dystrophies (DiMD), Duchenne muscular dystrophy (DMD), Emery-Dreifuss muscular dystrophy (EDMD), facioscapulohumeral muscular dystrophy (FSHD), limb-girdle muscular dystrophy (LGMD), myotonic dystrophy (MiD), and occulopharyngeal muscular dystrophy (OMD). These MDs' classifications are based on the clinical traits and age at onset, and they are subclassified according to their inheritance and the genetic bases of the disease [3,4]. Histopathologically, MDs are characterized by degeneration and necrosis of the muscle fibers, which are poorly regenerated and 
instead replaced by adipose and fibrotic tissue [5]. Another important trait of many MDs is chronic inflammation, as observed by the abundant presence of infiltrating inflammatory cells in dystrophic muscles. The persistent abundance of macrophages promotes the release of pro-fibrotic agents, including the transforming growth factor (TGF- $\beta$ ), that lead to excessive accumulation of extracellular matrix components, particularly collagen, and contribute to the formation of fibrotic tissue [5]. Another common feature in many MDs is the presence of oxidative stress (OS), which is characterized by the oxidation of lipids and proteins, and by the unbalance of the endogenous antioxidant systems [6]. Table 1 shows reported OS signs, inflammation markers and mitochondria traits, which are also involved in OS and inflammation as discussed later in different types of MDs.

Table 1. Muscular dystrophy types, genes involved and reported oxidative stress signs, inflammation markers and mitochondria traits in patients' biopsies and animal models.

\begin{tabular}{|c|c|c|}
\hline $\begin{array}{l}\text { Muscular Dystrophy } \\
\text { Type }\end{array}$ & Gene/Protein Associated & $\begin{array}{l}\text { Oxidative Stress Signs, Inflammation } \\
\text { Markers or Mitochondria Dysfunction }\end{array}$ \\
\hline $\begin{array}{l}\text { Becker muscular } \\
\text { dystrophy (BMD) }\end{array}$ & DMD/dystrophin & $\begin{array}{l}\text { Small inflammatory regions in patients' } \\
\text { muscles [7]. } \\
\text { Presence of inflammatory miRNAs [8]. }\end{array}$ \\
\hline $\begin{array}{l}\text { Congenital muscular } \\
\text { dystrophy (CMD) }\end{array}$ & $\begin{array}{c}\text { CHKB/choline kinase } \\
\text { COL6A1/collagen type VI, subunit } \alpha 1 \\
\text { COL6A2/collagen type VI, subunit } \alpha 2 \\
\text { COL6A3/collagen type VI, subunit } \alpha 3 \\
\text { DPM2/dolichyl-phosphate } \\
\text { mannosyltransferase polypeptide } 2 \\
\text { DPM3/dolichyl-phosphate } \\
\text { mannosyltransferase polypeptide } 3 \\
\text { FCMD/fukutin } \\
\text { FKRP/fukutin-related protein } \\
\text { TGA7/integrin } \alpha 7 \\
\text { TGA9/integrin } \alpha 9 \\
\text { LAMA2/laminin } \alpha 2 \text { chain of merosin } \\
\text { LARGE/like-glycosyl transferase } \\
\text { PABPN1/polyadenylate binding protein nuclear } 1 \\
\text { PTRF/polymerase I and transcript release } \\
\text { factor (cavin-1) } \\
\text { POMT1/protein-1-O-mannosyl-transferase } 1 \\
\text { POMT2/protein-1-O-mannosyl-transferase } 2 \\
\text { POMGNT1/protein-O-linked mannose } \\
\beta \text { 1,2-N-aminyltransferase } 1 \\
\text { SEPN1/selenoprotein N1 }\end{array}$ & $\begin{array}{l}\text { Inflammatory infiltrates in LAMA2-related } \\
\text { CMD [9]. } \\
\text { Mitochondria dysfunction in LAMA2-related, } \\
\text { Megaconial and Ullrich CMDs [10-14]. }\end{array}$ \\
\hline $\begin{array}{c}\text { Distal muscular } \\
\text { dystrophies (DiMD) }\end{array}$ & $\begin{array}{c}\text { DYSF/dysferlin } \\
\text { GNE/bifunctional UDP-N-acetylglucosamine } \\
\text { 2-epimerase/N-acetylmannosamine kinase } \\
\text { LDB3/Z-band alternatively spliced PDZ-motif } \\
\text { (ZASP) } \\
\text { MYH7/myosin heavy chain } \beta \\
\text { TIA1/Tia1 cytotoxic granule-associated rna binding } \\
\text { protein } \\
\text { TTN/titin }\end{array}$ & $\begin{array}{l}\text { Inflammatory infiltrates in Miyoshi } \\
\text { myopathy }[15,16] .\end{array}$ \\
\hline
\end{tabular}


Table 1. Cont.

\begin{tabular}{ccc}
\hline $\begin{array}{c}\text { Muscular Dystrophy } \\
\text { Type }\end{array}$ & Gene/Protein Associated & $\begin{array}{c}\text { Oxidative Stress Signs, Inflammation Markers or } \\
\text { Mitochondria Dysfunction }\end{array}$ \\
\hline $\begin{array}{c}\text { Duchenne muscular } \\
\text { dystrophy (DMD) }\end{array}$ & DMD/dystrophin & $\begin{array}{r}\text { Nucleotide oxidative products, oxidized glutathione } \\
\text { and lipid peroxidation [17-19]. }\end{array}$ \\
& & $\begin{array}{c}\text { Overexpression of pro-inflammatory cytokines [20]. } \\
\text { Infiltrating inflammatory cells in muscle biopsies of } \\
\text { DMD patients [21] }\end{array}$ \\
& $\begin{array}{c}\text { Mitochondria abnormality in patients' biopsies [22]. } \\
\text { Mitochondrial dysfunction in mdx mice [23]. }\end{array}$ \\
\hline
\end{tabular}

EMD/emerin

\begin{tabular}{ccc}
$\begin{array}{c}\text { Emery-Dreifuss muscular } \\
\text { dystrophy (EDMD) }\end{array}$ & $\begin{array}{c}\text { FHL1/four and a half LIM domain 1 } \\
\text { LMNA/lamin A/C } \\
\text { SYNE1/nesprin-1 } \\
\text { SYNE2/nesprin-2 }\end{array}$ & Altered oxidant status [24,25]. \\
\hline $\begin{array}{c}\text { Facioscapulohumeral } \\
\text { muscular dystrophy } \\
\text { (FSHD) }\end{array}$ & Unknown/DUX4 & Lipid peroxidation, protein carbonylation and DNA \\
oxidation [26].
\end{tabular}

ANO5/anoctamin 5

CAPN3/calpain-3

CAV3/Caveolin-3

DAG1/dystrophin-associated glycoprotein 1

DES/desmin

DYSF/dysferlin

FKRP/fukutin-related protein

FKTN/fukutin

LMNA/lamin A/C

MYOT/myotilin

Limb-girdle muscular

dystrophy (LGMD)

PLEC1/plectin 1

POMGNT1/protein-O-linked mannose

$\beta$ 1,2-N-aminyltransferase 1

POMT1/protein-1-O-mannosyl-transferase 1

POMT2/ protein-O-mannosyl-transferase 2

SGCA / $\alpha$-sarcoglycan

SGCB $/ \beta$-sarcoglycan

SGCD / $\delta$-sarcoglycan

SGCG $/ \gamma$-sarcoglycan

$\mathrm{TCAP} /$ titin cap

TRIM32/tripartite motif-containing 32

TTN/titin
Protein oxidation, lipid peroxidation, altered reduced glutathione and antioxidant enzyme activity in dysferlinopathy patients [27-29].

High levels of ROS, protein oxidation, lipid peroxidation, and antioxidant enzyme activity in dysferlin-deficient [30-33] and calpain-3 deficient mice [34].

Activation of nuclear factor kappa B and inflammasome in dysferin-deficient muscles [35]. Presence of the inflammatory markers Cd68 and Lgals3 in muscles of $\alpha$ - and $\delta$-sarcoglycan-deficient mice [36].

Mitochondria abnormality in skeletal muscle of d.ysferlinopathy patients [37] and calpain-3 deficient mice [34].

\begin{tabular}{ccc}
\hline $\begin{array}{c}\text { Myotonic dystrophy } \\
(\mathrm{MiD})\end{array}$ & $\begin{array}{c}\text { DMPK/myotonin-protein kinase } \\
\text { CNBP/cellular nucleic acid-binding protein }\end{array}$ & $\begin{array}{c}\text { Antioxidant imbalance in MiD patients [38]. } \\
\text { Mitochondria dysfunction in MiD patients [39]. }\end{array}$ \\
\hline $\begin{array}{c}\text { Occulopharyngeal } \\
\text { muscular dystrophy } \\
(\mathrm{OMD})\end{array}$ & PABPN1/polyadenylate-binding nuclear \\
protein 1 & Mitochondria dysfunction in an ice model of OMD \\
{$[40]$.}
\end{tabular}

The underlying pathomechanisms causing MDs are initiated by mutations in genes encoding proteins with dissimilar functions that, however, seem to converge in common cellular dysregulations resulting in OS and chronic inflammation. As we discuss here, MDs-causing mutations affect proteins critical to skeletal muscle integrity and homeostasis. Therefore, their defective forms or absence does not only cause particular cellular defects, but also activate signaling pathways that lead to OS and inflammation involving a positive feedback loop that contributes to the progression of MDs.

\section{Signs of Inflammation in the Skeletal Muscle}

Inflammation is a nonspecific mechanism driven by the immune system in response to harmful stimuli such as pathogen infection or damaged cells. Its purpose is to eliminate 
the cause of injury and to promote repair [41]. Inflammation occurs in vascularized tissue and is mediated by humoral and cell-factors that lead to leukocyte infiltration into the injured tissue. It has differentiated phases: acute, chronic, local and systemic. Acute inflammation is a highly regulated process that has a relatively short course and is solved once the noxious stimulus is removed [42]. Chronic inflammation is a long-lasting process, characterized by the proliferation of blood vessels, fibrosis and the simultaneous destruction and healing of the injured tissue [41]. Whereas local inflammation affects one organ or part of it, systemic inflammation affects the complete organism. In response to noxious stimuli, blood neutrophils and monocytes migrate towards the injured tissue. There, monocytes become macrophages that "engulf" the inflammatory-stimuli and release pro-inflammatory mediators promoting the recruitment of more immune-cells and amplifying the local acute inflammation [42]. At the peak of acute inflammation, pro-inflammatory molecules make a "transition" towards specialized pro-resolving mediators (SPMs) initiating the resolution of the local acute inflammatory response. Upon resolution, macrophages "switch" from a M1 pro-inflammatory to a M2 anti-inflammatory phenotype [42], facilitating this process. If this mechanism is dysregulated, pro-inflammatory signals persist and repair can be surpassed by damage, leading to chronic inflammation and tissue dysfunction that characterize the pathological conditions.

The skeletal muscle is a tissue permanently exposed to different traumas induced by contraction. Hence, it is constantly subjected to cycles of inflammation and repair. Skeletal muscles are organized in fascicles of between about 10 and 100 muscle fibers. These are long multinucleated cells whose nuclei are located in the periphery of the cell, not in the cell center [43]. Cylindrical organelles called myofibrils pack the contractile proteins myosin and actin. Each myofibril is organized into a variable number of sarcomeres, the functional unit for muscle contraction. The membrane of muscle fibers is called sarcolemma and presents deep invaginations named transverse tubules. Those are part of a network of endomembranes that surround myofibrils in association with the sarcoplasmic reticulum, the main intracellular store of $\mathrm{Ca}^{2+}$. One transverse tubule and two sarcoplasmic reticulumcisternae constitute the "muscle triad", the structural unit where the excitation-contraction coupling occurs [43]. Non-contractile elements provide structural support and facilitate the transmission of the force generated during contraction from sarcomere to all the muscle tissue. Among these elements are sarcolemmal-anchored proteins such as dystrophin; transmembrane proteins such as $\beta$-dystroglycan, sarcoglycan and integrins; and extracellular matrix-proteins such as the $\alpha$-dystroglycan and laminin-2 [44].

Under physiological conditions, most skeletal muscles are adaptable tissues that can undergo structural and functional modifications in response to different stimuli (i.e., use, hormonal and nutrient status, a process called muscle plasticity) [45]. In addition, and in response to intense exercise or injury, they are able to fully regenerate, recovering the number and/or the size of muscle-fibers [46]. The nuclei of muscle fibers do not undergo divisions; thus, under conditions in which muscle tissue must be repaired, the response is performed by muscle-stem cells called "satellite cells". These cells express the myogenic transcription factor Pax7 [47] and are located in a specialized region between the sarcolemma and the basal lamina in a state of "quiescence". After muscle injury, satellite cells are activated, becoming MyoD+ and myogenin+ myoblasts that undergo fusion and form syncytia, and upon innervation, they differentiate into mature fibers [47]. In addition to the activation of satellite cells, a time-dependent local acute inflammation is triggered in skeletal muscles after injury (Figure 1(A1)). This process is critical for the recruitment of immune cells that contribute to muscle regeneration [48]. At the onset of the muscle injury, the complement system is activated, promoting inflammatory cascades that lead to the infiltration of monocytes, neutrophils and T-cells $[49,50]$. Monocytes acquire a M1-proinflammatory profile that stimulates the proliferation of satellite-cells by releasing growth factors and proinflammatory cytokines (Figure 1(A1)) [51]. Among them tumor necrosis factor alpha (TNF $\alpha$ ), interleukin (IL)-6 and IL-15 act as promoters of the myoblast fusion and myotube formation [52,53]. These and other proinflammatory cytokines are also 
secreted by T-cells [54] importantly contributing to the process. Thereafter, a resolution phase proceeds in which M1 macrophages switch to M2 further promoting differentiation of myoblasts into myotubes, growth of muscle fibers (Figure 1(A2)) and skeletal muscle regeneration (Figure 1(A3)) [55-57]. In healthy conditions, these events resolve rapidly once the cause of injury has been "removed". However, in pathological contexts in which the stressor-agent persists the M1 to M2 transition is impaired becoming skeletal muscle inflammation chronic (Figure 1B). The latter might produce accumulation of fibrotic and fat tissue (Figure 1B), making regeneration inefficient and contributing to the pathophysiology of muscle diseases [58]. Persistent immune cells as well as muscle fibers release an exacerbated amount of proinflammatory cytokines enhancing the activation of signaling mediated by the nuclear factor kappa B (NF-kB), a key inductor of the transcription of pro-inflammatory genes (Figure 1B). Parallel the assembly of the NLRP3 inflammasome leads to the activation of the caspase- 1 enzyme and the subsequent proteolysis of proIL-1 $\beta$ and pro-IL-18 (Figure 1B) further promoting inflammation and perpetuating the inflammation/regeneration cycle (Figure 1B).

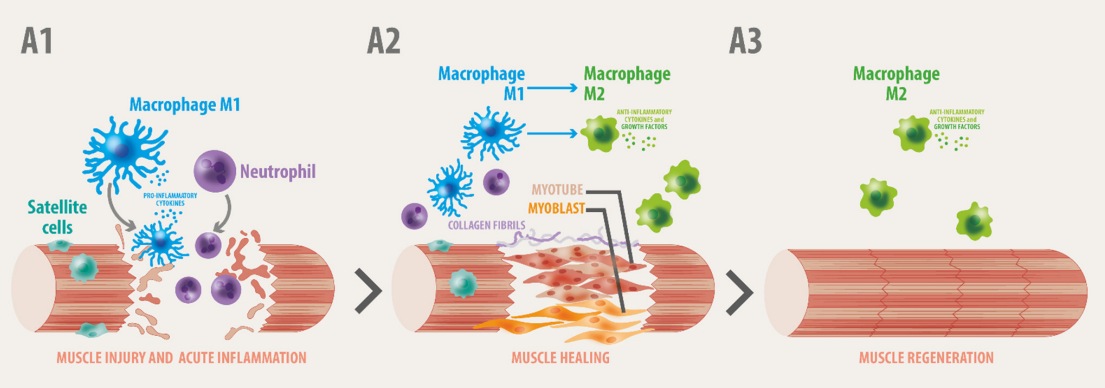

B

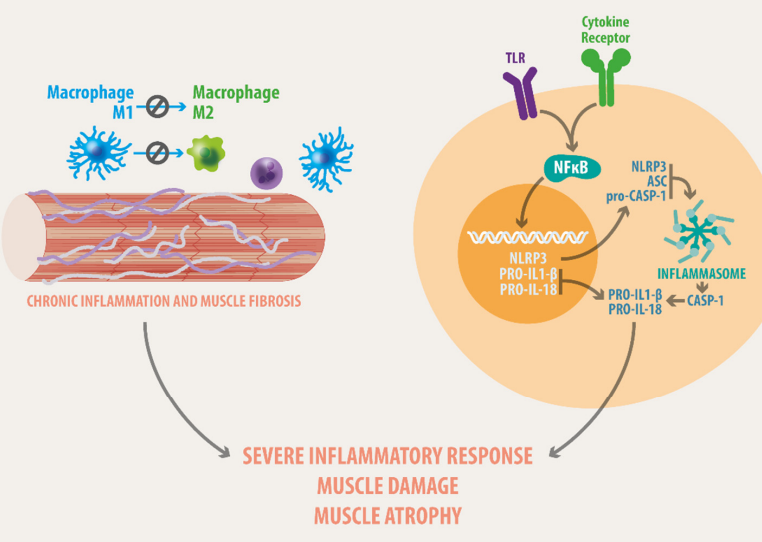

Figure 1. Inflammation in skeletal muscle healing and degeneration. (A1-A3) Upon muscle injury immune cells infiltrate, monocytes become macrophages with a proinflammatory M1-phenotype that release proinflammatory cytokines and growth factors promoting satellite cell proliferation (A1), myotube formation and muscle healing (A2) The transition from M1 to M2 pro-resolutive macrophages favors muscle regeneration (A3). (B) When these processes are deregulated the M1 to M2 transition is suppressed and inflammation becomes chronic, producing accumulation of fibrotic tissue and muscle dysfunction and atrophy. Proinflammatory cytokines bind to their receptors in inflammatory cells as well as in muscle cells, promoting the activation of the NFKB signaling, assembly of the NLRP3 inflammasome, activation of caspase- 1 and cleavage of the immature forms of the IL1 family (pro-IL1), thus enhancing inflammation and potentially contributing to muscle damage. Damage signals also activate toll-like receptors (TLRs), promoting the same mechanism. 
In MDs, mutated proteins critically affect the homeostasis of skeletal muscle, causing damage to the sarcolemma and contractile apparatus and leading to the persistence of the inflammatory events. The accumulation of proinflammatory mediators in the skeletal muscle tissue affects its regenerative capacity, impairing the healing mechanisms [58]. Consequently, muscle is replaced by fibrotic tissue and fat [5], leading to muscle dysfunction. Hence, chronic inflammation has been described in the context of different MDs. In the most severe forms of MDs, it progresses, affecting other muscles and tissues becoming a systemic chronic inflammation, which appears to contribute to the progressive muscle weakness and atrophy. Among MDs that reportedly develop with chronic inflammation are DMD [59], LGMD [35], merosin/laminin-deficient congenital muscular dystrophy [60], Miyoshi myopathy (MM) [15,16] and LMNA-related myopathies [61]. Chronic inflammation also appears to contribute to the atrophy in non-dystrophic myopathies such as in the valosin-containing-protein myopathy [62] and in the sporadic late-onset nemalinemyopathy [63].

\section{Chronic Inflammation in Skeletal Muscle Dystrophies}

DMD is the most frequent MD with an estimated worldwide prevalence of 4.78 per 100,000 births [64]. It is caused by X-linked mutations in the DMD gene encoding dystrophin. This protein is believed to be a component of the dystrophin glycoprotein complex (DGC) that connects the actin cytoskeleton with the extracellular matrix providing stability and structural integrity to the sarcolemma during muscle contraction [65]. DMD mutations produce dystrophin deficiency, leading to membrane depolarization, fragility, and high susceptibility to injury during muscle contraction [66]. Such defects associate to massive immune cell infiltration, chronic inflammation, and necroptosis, a programmed form of necrosis [67]. In this regard, mdx mice, a mammalian model of DMD, display an enhanced susceptibility to sarcolemma rupture under mechanical stress [68]. Upon DMD, skeletal muscles lose their ability to regenerate, resulting in fibrosis, early onset muscle dysfunction, and eventually loss of ambulation $[20,69,70]$. One variant of this disease is BMD. It is also caused by X-linked mutations in the dystrophin gene, but in this case, they preserve the reading-frame, allowing the expression of a partially functional truncated form of dystrophin [71,72]. Such differences result in a milder form of dystrophy in BMD, with a slower progression than that observed in DMD [72].

Local and systemic inflammation have been reported to be associated with the fibrosis and atrophy in DMD. Overexpression of pro-inflammatory cytokines such as IL-6, IL-1 $\beta$ and TNF- $\alpha$ [20], as well as anti-inflammatory cytokines such as IL-10 and TGF- $\beta$ [73], are chronically detected in DMD. The over-activation of the NF-kB (Figure 1B), has also been reported in DMD patients and animal models [69]. Congruently, the inhibition of NF-KB has been postulated as a potential therapeutic target in Duchenne. In 2016, Hammers and collaborators used the NF- $\mathrm{kB}$ inhibitors edasalonexent and CAT-1041 to treat the dystrophy in mdx mice. The oral administration of these NF- $\mathrm{kB}$ inhibitors, which were composed by omega-3- polyunsaturated fatty acids (PUFAS) conjugated to salicylic acid, improved the dystrophic phenotype in terms of activity and muscle mass, reduced inflammation and fibrosis [74]. In the same line, treatment with eicosapentaenoic acid (EPA) has further shown to protect against the muscle damage in the $\mathrm{mdx}$ mice by promoting a shift from the M1 to M2 macrophage phenotype [75]. In placebo-controlled, double-blind, randomized trials carried out in DMD patients, treatment with EPA and docoshexaenoic acid (DHA) reduced inflammation markers and diminished the expression of NF- $\mathrm{kB}$ in leukocytes [76,77]. Furthermore, in phase 2 and 3 clinical trials in DMD young patients, NF- $\mathrm{KB}$ inhibitors such as flavocoxid or edasalonexent, showed to reduce the serum levels of IL-1 $\beta$ and TNF- $\alpha$, slowed-down the disease progression and preserved muscle function [78-80], indicating that NF- $\mathrm{kB}$ might be a promising targeted therapy for MDs.

Another important mediator of the inflammatory process that is over-active in neuromuscular diseases including DMD is the NLRP3 inflammasome [81]. Inflammasomes are cytosolic-receptors of the innate immune system that assemble in response to harmful 
stimuli, mediating the activation of caspase-1 [82] (Figure 1B). This enzyme catalyzes the proteolytic processing of inactive precursors of IL-1 $\beta$ and IL-18, turning them into their active forms [82] and promoting inflammation (Figure 1B). The NLRP3 inflammasome is also expressed in skeletal myofibers [35] and its inhibition has been evaluated as a potential therapeutic target in DMD. In 2018, Boursereau and collaborators demonstrated that Adiponectin $(\mathrm{ApN})$, an adipocyte-secreted cytokine that regulates glucose and fatty-acid metabolism [83], exerts downregulation of NLRP3 via the micro-RNA miR-711 [59]. Congruently, overexpression of $\mathrm{ApN}$ seems to protect skeletal muscle against inflammation and injury, as well to improve the muscle function in $\mathrm{mdx}$ mice [84]. The positive regulation of the ApN receptor reduced infiltration of T-cells and promoted the transition from M1 to M2 macrophages in the muscles of mdx mice, promoting regeneration [85]. More recently, AdipoRon, an ApN-receptor agonist, has been used in mdx mice with similar results. The oral administration of AdipoRon for eight weeks managed to protect the mdx skeletal muscle against chronic inflammation and OS, attenuating the dystrophic phenotype [86]. In the same line ghrelin, another metabolic hormone that participates in the regulation of the appetite, exerts a similarly positive effect and has been suggested as a potential candidate for the DMD treatment. Ghrelin possesses anti-inflammatory activity, prevents skeletal muscle atrophy, increases muscle regeneration, and improves the dystrophic phenotype rescuing the muscle function in $m d x$ mice [87]. As with $A p N$, the ghrelin action seems to rely on the inhibition of the NLRP3 inflammasome assembly [87].

In addition to the evidence reported in the DMD context, inflammation has been also described as part of the pathological mechanisms in other MDs. Merosin/laminin- congenital muscular dystrophies, EDMD, and LGMD constitute other examples of inflammatory diseases. The merosin-deficient congenital muscular dystrophy type 1A (MDC1A) is caused by mutations in the LAMA2 gene [60] that lead to the partial or complete absence of $\alpha 2-$ laminin. This protein, also called merosin, is a component of the extracellular matrix (ECM) that links the ECM to the DGC and to the sarcolemma-associated integrin complex [46]. Consequently, merosin plays a critical role in the maintenance of the sarcolemma integrity and muscle function. Mutations in other genes that code components of the ECM, such as the collagen type VI, are associated with other MDs, including Bethlem myopathy and Ullrich-scleroatonic muscular dystrophy [88]. The expression of merosine in satellite cells is associated with the proliferation and differentiation of myogenic cells [46]. Consequently, MDC1A-causing mutations in the LAMA2 gene lead to a defective muscle repair associated with chronic inflammation, fibrosis, and muscle atrophy [89]. Clinical symptoms of MDC1A include severe muscle atrophy, progressive muscle weakness, joint contractures, breathing and feeding difficulties [60]. Most patients lose their ambulation in infancy and exhibit a drastic shortening of their lifespan [89]. In skeletal muscle of patients and mouse models of MDC1A, an early onset of chronic inflammation occurs, leading to cycles of degeneration/regeneration and accumulation of fibrotic lesions [60]. In DyW mice, a murine model of laminin-deficient muscular dystrophy, merosin-deficient skeletal muscles exhibit high macrophage infiltration from early ages to adulthood. This infiltration is accompanied by an increase in the NF- $\mathrm{kB}$ signaling and over-expression of pro-inflammatory cytokines, which favors inflammation and causes inhibition of myogenesis [89].

EDMD is an early onset dystrophy characterized by slowly progressive muscle atrophy and weakness, spinal stiffness and heart disease. The overall prevalence of EDMD is unknown, but it is estimated to be the third most prevalent muscular dystrophy with an estimated of 1 case per 100,000 newborns [90]. EDMD is mostly caused by X-linked mutations in the EMD gene encoding emerin and by autosomal mutations in the LMNAgene encoding lamin A/C [90]. Mutations in these genes have a negative impact on several functions of the nuclear envelope, such as the nuclear structure, cell signaling, and gene expression [61]. Mutations in lamin A/C and laminin-binding proteins are associated with the activation of the transcription factor NF- $\mathrm{kB}$ and with the consequent secretion of proinflammatory cytokines. A 2018 study carried out by Cappelletti et al. [61] demonstrated that myoblasts from patients with mutations in the LMNA gene secrete high amounts of 
pro-inflammatory cytokines, such as IL-6 and IL-8, in a similar way to what occurs with factors secreted by senescent cells or persistently damaged cells. In fact, mutations in the LMNA gene cause structural lesions of the nuclear lamina in macrophages, inducing a modification of their adhesive properties and promoting their infiltration in skeletal muscles [61].

Mutations in sarcoglycan components of the DGC lead to LGMD [91]. It is a heterogeneous group of MDs that primarily affects shoulders and hips. Its clinical manifestations range from severe forms with neonatal-onset to milder late-onset and slowly progressive forms. Mutations in genes encoding the caveolae-associated protein caveolin-3 [92], the $\mathrm{Ca}^{2+}$-regulated proteolytic enzyme calpain-3 [93], the component of intermediate filaments desmin [94], the giant sarcomeric protein titin [95] or the glycosyltransferaseenzymes are also associated with different forms of LGMD [3]. Recessive mutations in the DYSF gene, which encodes the protein dysferlin, cause LGMD type 2B (LGMD2B) and MM [96]. Dysferlin is expressed in skeletal and cardiac muscle cells, as well as in monocytes and macrophages playing a key role in membrane fusion and repair [97]. It interacts with annexin-A1 and annexin- $\mathrm{A} 2$, which are $\mathrm{Ca}^{2+}$-binding molecules involved in the sarcolemma-repair [97]. The membrane-repairing function in dysferlin-deficient myofibers can be recovered in dysferlinopathy models by expressing a "mini-dysferlin" peptide or myoferlin, another ferlin family protein, but these approaches do not arrest muscular degeneration [98]. In this regard, an additional function of dysferlin has been proposed, which could be implicated in the pathological mechanisms of dysferlinopathy. As dysferlin has been localized in intracellular vesicles [99], regulates the cytoskeletal actin remodeling [100] and has been detected in non-mechanically active tissues including endothelial cells, where its absence causes deficient trafficking of membrane-bound proteins [101], it is likely that dysferlin acts as a mediator in the traffick of other proteins. Thus, the main dysferlin dysfunction caused by dysferlinopathy-linked mutations requires further study. In this regard, the mechanisms contributing to the onset and progression of this type of LGMD are not yet fully defined, although mutations in the DYSF gene are associated with the loss of dysferlin expression and seem to compromise the capability of myofiber for repair following sarcolemmal injury. The latter leads to chronic inflammation, degeneration, and gradual adipogenic replacement of the muscle tissue [97]. This has been demonstrated through the involvement of immune factors in the pathogenesis of dysferlinopathy [102]. In fact, the absence of dysferlin favors intramuscle macrophage recruitment, proliferation, and skews macrophages toward a cyto-destructive phenotype [103]. As activated macrophages are a rich source of radical species and proinflammatory cytokines, their infiltration in muscles exacerbates local damage. In fact, several studies suggest that these mediators make dysferlin-deficient muscles more vulnerable to damage. Remarkably, the suppression of the innate-immune response mediated by toll-like receptors (TLRs) has been shown to reduce the atrophy and improve muscle strength in a dysferlin-deficient mouse model [104]. These data are consistent with the research carried out by Rawat et al. in 2010 [35], who showed that TLR-mediated signaling pathways trigger an inflammatory response that involves the activation of NF- $\mathrm{KB}$ and the assembly of the NLRP3 inflammasome in the dysferin-deficient dystrophic muscles [29,35].

Acute inflammation is necessary to trigger a repair-program that regenerate muscles after injury [48]. However, the mechanisms that transform this process in a chronic condition contributing to muscle degeneration remain poorly understood. A possible explanation could be related to the large amount of reactive oxygen species (ROS) produced by the inflammatory cells, such as macrophages and neutrophils, which infiltrate the skeletal muscle damaged [41]. As chronic inflammation seems to be importantly involved in the progression of MDs, this is an aspect to be considered in the search of new potential therapeutic targets. 


\section{Oxidative Stress in Muscular Dystrophies}

In biology, ROS are endogenous molecules produced by different tissues under physiological conditions, although they can be overproduced in pathological states. In the skeletal muscle, $\mathrm{ROS}$ such as the radical superoxide $\left(\mathrm{O}_{2}{ }^{--}\right)$and its dismutation product hydrogen peroxide $\left(\mathrm{H}_{2} \mathrm{O}_{2}\right)$ are transiently produced during high metabolic demand and ATP depletion, for instance during physical activity [105]. Major sources of ROS include mitochondria [106], purine metabolism by xanthine oxidase [107], oxygenases that metabolize arachidonic acid (lipoxygenases and cyclooxygenases) [108] and the nicotinamide adenine dinucleotide phosphate (NADPH) oxidase complex (Figure 2) [109]. The main source of $\mathrm{O}_{2}{ }^{--}$during exercise comes from the activation of the NADPH-oxidase (NOX) complex [110]. This membrane-bound enzyme system catalyzes the $\mathrm{O}_{2}{ }^{\bullet-}$ production by transferring an electron from NADPH to the diatomic oxygen $\left(\mathrm{O}_{2}\right)$. During exercise, the NOX system seem to be stimulated by either membrane depolarization or protein kinase C (PKC) activation [111,112]. PKC activation results from a positive feedback loop generated by the release of ATP through pannexin channels with the consequent activation of purinergic P2Y1 receptors [112,113]. Increased levels of NADH during contraction can also contribute to $\mathrm{O}_{2}{ }^{\bullet-}$ production via the NOX system [110]. In addition, activation of the insulin receptor in skeletal muscle cells constitutes an additional mechanism for ROS production, as it promotes the activation of NOX, through a mechanism that involves phosphoinositide 3-kinase (PIK3) and PKC [114]. In turn, ROS production during physical activity favors $\mathrm{Ca}^{2+}$ release through the ryanodine receptor [115] and contributes to about $50 \%$ of glucose uptake through the glucose transporter 4 (GLUT4) [116]. This mechanism requires the translocation of GLUT4 from intracellular stores towards the sarcolemma and transverse tubules [117]. The contraction-induced GLUT4 translocation is impaired when muscles are pre-incubated with ROS-scavengers [118], suggesting that ROS are necessary for contraction-mediated glucose uptake. Upon moderate exercise, the small GTPase Rac1 is activated, promoting actin polymerization and consequently favoring the actin-mediated GLUT4-translocation [119]. In this regard, mice deficient in Rac1 or the NOX2 subunit p47phox exhibit a reduced ROS production and impaired glucose uptake in response to moderate exercise [116]. It has also been reported that ROS participate in exerciseinduced mitochondrial adaptations [120], via a mechanism that involves the nuclear factor erythroid-derived 2-related factor 2 (Nrf2) [121]. Major mitochondrial changes produced by endurance-training in response to exercise are modifications in their content, biogenesis, fusion and segmentation [122].

Skeletal muscles also produce reactive nitrogen species (RNS) such as nitric oxide $\left(\mathrm{NO}^{\bullet}\right)$, peroxynitrite $\left(\mathrm{ONOO}^{-}\right)$, nitroxyl $(\mathrm{HNO})$ and nitrosonium cation $\left(\mathrm{NO}^{+}\right)$, among others [123]. $\mathrm{NO}^{\bullet}$ is a highly diffusible molecule with a very short biologic half-life $(0.1-2 \mathrm{~s})$ that under physiological conditions acts as a second messenger by stimulating the guanylyl cyclase (GC) and cyclic guanosine monophosphate (cGMP) pathways. During contraction, $\mathrm{NO}^{\bullet}$ is generated by the activation of the splice variant $\mu$ of the neuronal nitric oxide synthase (nNOS), via a mechanism that seems to be mediated by the $\mathrm{nNOS} \mu$ phosphorylation by AMPK [124]. In turn, the NO` produced during contraction reportedly acts as a paracrine vasodilator that counteracts the sympathetic vasoconstriction produced during exercise [125]. It has been also proposed that $\mathrm{NO}^{\bullet}$ promotes glucose uptake [124]. However, glucose uptake in gastrocnemius muscle during exercise is not impaired in nNOS $\mu$-knock-out (KO) mice [126]. It is therefore possible that other $\mathrm{NO}^{\bullet}$ sources or mechanisms contribute to the exercise-induced glucose uptake. 


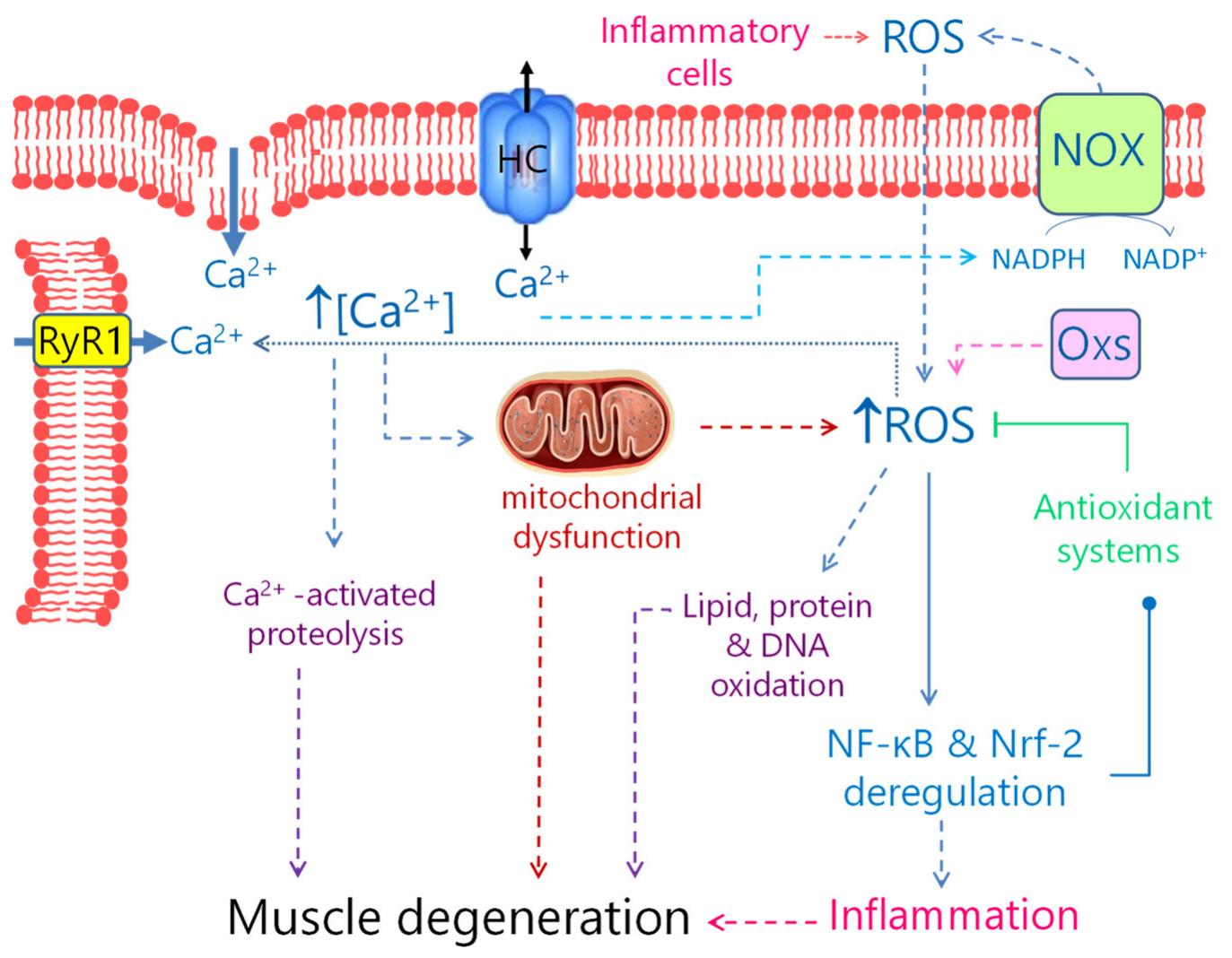

Figure 2. Mechanisms contributing to muscle dystrophy progression. Mutations in proteins that critically regulate skeletal muscle integrity and homeostasis can cause myofiber damage with consecutive accumulation of inflammatory cells that produce ROS. In muscular dystrophies (MDs), such as Duchenne muscular dystrophy (DMD), myofibers also display sarcolemma microtears that allow $\mathrm{Ca}^{2+}$ entry. The de novo expression of non-selective channels, such as connexin hemichannels, can further contributes to excessive high cytosolic $\mathrm{Ca}^{2+}$ concentrations, which in turn might lead to activation of $\mathrm{Ca}^{2+}$-activated proteases, mitochondria dysfunction and reactive oxygen species (ROS) generation from mitochondria, NADPH-oxidase (NOX) and oxidases (Oxs) such as xanthin oxidase. ROS overproduction leads to $\mathrm{Ca}^{2+}$ leak from the sarcoplasmic reticulum via ryanodine receptors (RyR1), oxidation of lipids, proteins and DNA, and deregulation of the nuclear factor kappa B (NF- $\mathrm{kB}$ ) and nuclear factor erythroid-derived 2-related factor 2 (Nrf2) signaling pathways, which regulate the expression of inflammatory mediators and antioxidant enzymes. All these elements contribute to muscle degeneration.

Although moderate levels of ROS are necessary for normal contraction and force production, the excess of ROS can lead to muscle fatigue and contractile dysfunction [105]. Under physiological conditions different enzymes, such as superoxide dismutase (SOD), catalase, glutathione peroxidase and thioredoxin reductase, and antioxidant endogenous molecules such as glutathione (GSH), prevent ROS accumulation [105]. Either catalase or glutathione peroxidase reduce $\mathrm{H}_{2} \mathrm{O}_{2}$ to $\mathrm{H}_{2} \mathrm{O}$. On the other hand, RNS can be neutralized by hemoglobin, uric acid, $\beta$-carotene, vitamins $\mathrm{E}$ and $\mathrm{C}$, as well as by SOD, glutathione peroxidase and thioredoxin [127]. These antioxidant systems allow a fine-tune balance of ROS levels, and disruption of this equilibrium can cause OS, a condition implicated in the progression of different skeletal muscle affections, including sarcopenia and different types of myopathies $[6,128]$. The redox imbalance may be due to an increased production of $\mathrm{O}_{2}{ }^{\bullet-}$ or a reduced neutralization of ROS and RNS. Thus, persistent high levels of $\mathrm{O}_{2}{ }^{\bullet-}$ and $\mathrm{H}_{2} \mathrm{O}_{2}$ may release metal ions, such as copper and iron, from their respective protein complexes to favor the production of hydroxyl radical $\left(\mathrm{HO}^{\bullet}\right)$ by a Fenton-type reaction mechanism [129]. $\mathrm{HO}^{\bullet}$ is one of the most reactive $\mathrm{ROS}$ that has an oxidative potential of $1.9 \mathrm{~V}$ at $\mathrm{pH} 7.0$ and a half-life of $10^{-9} \mathrm{~s}$, properties that mean that its harmful 
actions may be limited to a restricted area [130]. As $\mathrm{O}_{2}{ }^{\bullet-}$ can react with $\mathrm{NO}^{\bullet}$ to generate $\mathrm{ONOO}^{-}$, another strong oxidant that further reacts with carbon dioxide $\left(\mathrm{CO}_{2}\right)$ to form the radicals $\mathrm{CO}_{3}{ }^{\bullet-}$ and $\mathrm{NO}_{2}{ }^{\bullet-}$, or the adduct $\mathrm{ONOOCO}_{2}^{-}$[127], high levels of ROS can also trigger nitrosative stress. These different ROS and RNS can produce post-translational modifications such as oxidation, S-nitrosylation, S-glutathionylation or S-tyrosine-nitration of proteins, lipid peroxidation, and oxidation and nitration of nucleic acids (Figure 2), thus causing disfunction of different cellular elements and processes and deleterious effects to cells $[127,131]$. Furthermore, high ROS generation can also activate cellular signaling pathways that lead to apoptosis or necrosis, such as the c-Jun N-terminal kinases (JNK)/p53 pathway [132] and receptor-interacting serine/threonine protein kinase (RIP) 1 and 3 complexes [133], respectively. Among the target proteins susceptible to modification by ROS is NF-кB [134]. As aforementioned, this signaling is involved in different skeletal muscle physiological processes, but, its chronic activation has been observed in different skeletal muscle disorders, including MDs $[29,89,135]$. ROS can both directly modify NF$\kappa \mathrm{B}$ and its upstream kinases, and these can lead to either activation or repression of the NF- $\mathrm{KB}$ signaling (Figure 2); in turn, NF- $\mathrm{KB}$ activation can promote either anti- or prooxidant responses [136]. In this case, the interplay between ROS and NF- $\mathrm{BB}$ depends on the context and stage of the muscle redox state. ROS can also influence the activity of the Nrf2 (Figure 2). Under OS, this nuclear factor translocates to the nucleus to promote the expression of many antioxidant enzymes that render protection upon a stronger OSpromoting condition [137]. In contrast, its deficiency enhances ROS-induced damage in dystrophic muscles [31], whereas its activation seems to mitigate the progress of these diseases [69], presumably acting as a preconditioning factor.

A critical interplay during OS is which occurs between ROS and mitochondria, the main source for ATP production in skeletal muscles during aerobic respiration. These organelles also produce ROS as a result of the electron leakage at the electron transport chain during basal respiration [138]. The $\mathrm{O}_{2}{ }^{\bullet-}$ generated, less than $1 \%$ of the total fraction of $\mathrm{O}_{2}$ utilized [139], is neutralized by the Mn-SOD (SOD2) and Cu, Zn-SOD (SOD1) present in the mitochondrial matrix and intermembrane space, respectively [140]. However, ROS production by mitochondria drastically increases under danger signals, as observed during MDs (Figure 2), wherein proinflammatory cytokines, or high levels of cytosolic $\mathrm{Ca}^{2+}$ and $\mathrm{Na}^{+}$ that reduced the mitochondrial membrane potential promote mitochondrial ROS generation [141]. During physiological $\mathrm{Ca}^{2+}$ signals, mitochondria uptakes $\mathrm{Ca}^{2+}$ from the cytosol essentially through a uniporter $\mathrm{Ca}^{2+}$ channel in the inner mitochondrial membrane [142]. This $\mathrm{Ca}^{2+}$ uptake stimulates the oxidative metabolism in the mitochondrial matrix by regulating Kreb cycle enzymes, such as the isocitrate-dehydrogenase, $\alpha$-ketoglutarate dehydrogenase and pyruvate dehydrogenase [143]. However, excessively high cytosolic $\mathrm{Ca}^{2+}$ concentrations overcharge the mitochondrial $\mathrm{Ca}^{2+}$, inducing the constant opening of the mitochondrial permeability transition pore, a non-specific pore that allows the passage of molecules of $<1.5 \mathrm{kDa}$ to the mitochondria matrix [144]. A high and persistent conductance of this pore can lead to osmotic swelling, rupture of the outer membrane, and metabolic collapse [145]. Furthermore, OS can also induce an imbalance in mitochondrial fission-fusion, promoting their fragmentation [146], thus contributing with an additional mechanism inducing cell damage.

OS has been found in different types of MD, being more extensively studied in DMD. Indeed, OS signs, such as nucleotide oxidative products, oxidized glutathione or lipid peroxidation products, have been found in patients with DMD [17-19] and animal models of the disease $[147,148]$. An oxidative imbalance has also been reported in other MDs such as the LGMD2B and MM caused by dysferlin mutations. In this regard, muscle biopsies of patients suffering from dysferlinopathy show increased levels of protein oxidation and lipid peroxidation and altered reduced glutathione and antioxidant enzyme activity [27-29]. Dysferlin-deficient A/J mice also show high levels of ROS in flexor digitoris brevis (FDB) myofibers [30,31] and protein thiol oxidation in quadriceps [32]. As we recently reported, quadriceps and gastrocnemius muscles of dysferlin-deficient Bla/J mice, another model 
of dysferlinopathy, exhibit high levels of protein oxidation and lipid peroxidation and altered activity of the antioxidant enzymes superoxide dismutase and catalase [33]. In this regard, the treatment of dysferlin-deficient Bla/J mice with the antioxidant agent $\mathrm{N}$-acetylcysteine reduces the OS signs and appears to improve muscle strength and/or resistance to fatigue [33]. A common feature that might induce OS in MDs is the absence or malfunction of sarcolemma integrity-associated proteins such as dystrophin and dysferlin, which can lead to an altered $\mathrm{Ca}^{2+}$ homeostasis (Figure 2) $[96,149,150]$. The mechanism by which these types of MDs show altered $\mathrm{Ca}^{2+}$ levels is not clear, and it has been proposed that it is a consequence of a non-specific $\mathrm{Ca}^{2+}$ influx through microtears in the sarcolemma (Figure 2) $[149,150]$. However, as we discuss later, the de novo expression of connexin (Cx) hemichannels and overexpression of pannexin (Panx) might further contribute to the $\mathrm{Ca}^{2+}$ dyshomeostasis in MDs such as DMD and dysferlinopathy (Figure 2) [151,152]. Importantly, the interplay between the $\mathrm{Ca}^{2+}$ homeostasis and ROS is bidirectional. Indeed, persistent high intracellular $\mathrm{Ca}^{2+}$ levels can contribute to mitochondrial $\mathrm{Ca}^{2+}$ overload, NOX-activation and ROS overproduction (Figure 2) [153,154]. In turn, ROS production by NOX4 contributes to the S-nitrosylation of the ryanodine receptor 1 (RyR1), increasing the $\mathrm{Ca}^{2+}$ leak from the sarcoplasmic reticulum (Figure 2) [154].

An altered oxidant status has also been found in EDMD [24,25]. This skeletal muscle disorder is caused by mutations in the gene encoding lamin $\mathrm{A} / \mathrm{C}$ that increase the basal levels of ROS and lead to mitochondrial dysfunction [155]. It has been hypothesized that conserved cysteine residues in the lamin A C-terminal neutralize ROS, thus preventing protein oxidation [156]. It has also been proposed that lamin-A mutations associated to EDMD induce an atypical nuclear localization of the stress responsive protein Ankrd2, increasing the susceptibility to ROS damage [157]. On the other hand, muscle-specific expression of the mutant lamins in Drosophila produced reductive stress caused by cytoplasmic protein aggregation [158].

An increased susceptibility to ROS has also been observed in FSHD [159]. OS signs such as high levels of lipid peroxidation, protein carbonylation and DNA oxidation, and mitochondrial dysfunction have been found in skeletal muscles biopsies and blood samples from FSHD patients [26]. This muscle affection was initially associated with hypomethylation of a region known as D4Z4 in the chromosome 4q35, which contains the double homeobox 4 (DUX4) gene. However, recent analyses show that the D4Z4 hypomethylation did not correlate with the disease status $[160,161]$ and, instead, it seems to be due to the chromatin structure present in the contracted allele [161]. Immortalized human myoblasts expressing DUX4 exhibit high levels of ROS [162], and in turn, OS increases the DUX4 expression [163]. In this regard, a transcriptome analysis in DUX4-expressing myoblasts identified 200 genes relevant for the FSHD pathogenesis that are deregulated by DUX4 indirectly, through OS [162]. Interestingly, silencing one of such genes managed to restore the differentiation ability of DUX4-expressing myoblasts [162].

\section{Connexin and Pannexin Channels in Muscular Dystrophies}

The Cx gene family comprises 20 members in mice and 21 genes in the human genome, of which 19 can be grouped as orthologous pairs [164]. These proteins form poorly selective membrane channels called hemichannels, which are present in the cell membrane of most cell types allowing communication between the cytoplasm and the extracellular medium. In addition, Cxs can form gap junction channels that communicate the cytoplasm of cells in contact [165]. Cx hemichannels also participate in autocrine and paracrine communication, as they are permeable to different small metabolites and molecules involved in cell signaling, such as glucose, NAD+, NO, prostaglandin E2, glutamate, and ATP [166]. In addition, some of them (i.e., Cx26 and Cx43) have been shown to be permeable to $\mathrm{Ca}^{2+}[167,168]$, whereas others (i.e., Cx39) might be rather impermeable to this divalent cation [169].

Other poorly selective channels are those constituted of Panx, a family of glycoproteins composed of 3 members, Panx1-3 [170]. Panx1 is ubiquitously expressed in various tissues, while Panx2 is primarily expressed in the central nervous system [171]. Panx3 is 
found in bone, skin, and skeletal muscles [170,172]. Panx1 channels localize in the cell membrane and play a relevant role in the release of ATP from different cell types [170]. Different stimuli capable of activating Panx1 channels have been reported, including voltage [173], membrane stretching [174,175], intracellular $\mathrm{Ca}^{2+}$ augmentation [175,176], and its C-terminal domain proteolysis [177]. However, it was recently shown that Panx1 is not directly sensitive to stretching instead, stretch stimulates other channels that allow the entry of $\mathrm{Ca}^{2+}$ promoting the activation of the $\mathrm{Ca}^{2+} /$ calmodulin-dependent protein kinase II (CaMK 11), which phosphorylates Panx1, causing a conformational change of the channel that allows the passage of ATP through its "lateral tunnels" [175].

In skeletal muscles, myoblasts express $\mathrm{Cx}$-based hemichannels and gap junction channels essential during myogenesis [178]. However, at terminal stages of the myogenesis, the expression of Cxs is inhibited [178] in a manner dependent on the release of acetylcholine by motoneurons [179]. In the adult stage, skeletal muscles present a preform Cx mRNA [179], suggesting that they might be rapidly translated under particular conditions which are not yet identified. Indeed, the expression of Cxs 39, 43 and 45 occurs transiently during regeneration after damage $[180,181]$. On the other hand, the expression of Panx1 is very low in undifferentiated myoblasts but drastically increases upon muscle differentiation, playing a key role in this process [182,183].

The de novo expression of Cx-hemichannels has been implicated in skeletal muscle inflammation by acting as a pathway for the release of ATP which is the source of extracellular adenosine that mediate preconditioning [184]. In addition, preconditioning has been associated to the translocation of $\mathrm{Cx} 43$ to the mitochondria where it can affect the distribution of $\mathrm{K}^{+}$across the inner membrane [185]. On the other hand, metabolic inhibition increases plasma membrane expression, nitrosylation and opening of $\mathrm{Cx} 43$ hemichannels [186] and nitrosylation at the residue C271 promotes the opening of Cx43 hemichannel, as observed in mdx mouse-cardiomyocytes [187]. A crosstalk between Cx hemichannels and OS has also been demonstrated, as inhibition of Cx hemichannels protects cells from OS [188-190] and Cx hemichannels are inhibited by antioxidant agents such as resveratrol and $\alpha$-tocopherol and partially nhibited by $\mathrm{N}$-acetylcysteine [191]. Therefore, in addition to the intrinsic antioxidant effects of some compounds, their protective effect could include prevention of the rise in intracellular $\mathrm{Ca}^{2+}$ signaling known to activate several metabolic pathways that generate superoxide anion as described above. Remarkably, myofibers deficient in Cx43 and Cx45 expression do not present mitochondrial dysfunction induced by a synthetic glucocorticoid, suggesting that mitochondrial impairment occurs downstream of de novo $\mathrm{Cx}$ hemichannel expression, which reduces the membrane potential and consequently reduces the ionic asymmetry across the sarcolemma, affecting normal mitochondrial functioning [191].

In the pathological context of MDs, Cx and Panx hemichannels have been implicated. Panx1 over-expresses, together with the de novo expression of $\mathrm{Cx}$ hemichannels, contributing to increase the permeability of the sarcolemma [151,152]. In mdx mice, in which the absence of dystrophin is associated with an increase in the intracellular $\mathrm{Ca}^{2+}[149,150]$ that lead to myofiber necrosis [192], the de novo expression of Cx39, Cx43 and Cx45 has been demonstrated [151]. Interestingly, mdx mice in which a myofiber-specific $\mathrm{KO}$ of $\mathrm{Cx} 43$ and Cx45 was performed, presented normal intracellular $\mathrm{Ca}^{2+}$ signals, absence of myofiber apoptosis, reduced myofiber necrosis and improved muscle function [151]. The latter strongly suggests that a $\mathrm{Cx}$ hemichanel-mediated $\mathrm{Ca}^{2+}$ dyshomeostasis could importantly contribute to the pathophysiology of MDs (Figure 2). The role of elevated cytoplasmic $\mathrm{Ca}^{2+}$ in cell death is supported by experiments in which the overexpression of the transient receptor potential canonical 3 (TRPC3) in myofibers leads to increased $\mathrm{Ca}^{2+}$ influx, resulting in a dystrophic phenotype [192]. On the contrary, the transgenic suppression of TRPC channels in mdx mice reduced the $\mathrm{Ca}^{2+}$ influx and dystrophic signs [192]. However, in these studies the sarcolemma's permeability to Evans blue is not observed, and rather is completely abrogated in myofibers deficient in Cx43 and Cx45 [151,152], indicating that 
Cx hemichannels and not sarcolemma microtears are the initial step of myofiber damage in MDs.

Panx1 channel expression is also enhanced in mdx mice [151,172,193]. It is accompanied by an increase in the Panx1-mediated ATP release, which promotes the increase in the intracellular $\mathrm{Ca}^{2+}$. In this respect, it was shown that the treatment with the L-type voltage-dependent- $\mathrm{Ca}^{2+}$-channel inhibitor nifedipine reduced the extracellular ATP levels in mdx myofibers by reducing the intracellular $\mathrm{Ca}^{2+}$ concentration [193]. The nifedipine treatment also reduced the expression of the NOX2 system, which is overexpressed in the diaphragm of mdx mice where it associates to the overproduction of ROS and decreased respiratory function [193]. At the level of cardiac muscle, there is an aberrant expression of $\mathrm{Cx} 43$ hemichannels in mdx mice, which is associated with an altered $\mathrm{Ca}^{2+}$ signaling. Congruently, a reduction in the $\mathrm{Cx} 43$ hemichannel activity seems to improve $\mathrm{Ca}^{2+}$ signaling, as well as to reduce NOX2 and ROS production, protecting mdx mice from inducible arrhythmias and cardiomyopathies [194]. In addition, it has been reported that the suppression of Cx43 decreases the activation of the inflammasome, which was preceded by a decrease in the production of ROS and NOX2 [195]. In turn, OS alters the subcellular localization of Cx43 in the heart [196] and modifies the normal transport of Cxs from intercalated discs towards the lateral membrane, affecting excitability of the cardiomyocyte membrane [196]. However, the subcellular location of Cxs has not yet been studied in pathologies that affect skeletal muscle. On the other hand, NOX inhibition in dystrophic cardiomyocytes reduced Cx43 hemichannel activity, probably due to decreased nitrosylation [197].

In dysferlinopathy, a de novo expression of Cxs 39, 43 and 45 has also been reported [151,198,199]. As discussed above, it is accompanied with inflammation [35] and intracellular $\mathrm{Ca}^{2+}$ deregulation [151,152]. In human myoblasts lacking dysferlin, the de novo expression of $\mathrm{Cx} 40.1$, an ortholog of the rodent $\mathrm{Cx} 39$, has been reported in addition to Cxs 43 and 45 [152]. Similarly, skeletal muscles of blAJ mice exhibit an elevated expression of Cx39, 43 and 45 associated to elevated basal intracellular $\mathrm{Ca}^{2+}$ in myofibers, and muscle atrophy and lipid accumulation [198,199]. Remarkably, the downregulation of Cx43 and Cx45 prevents increases in intracellular $\mathrm{Ca}^{2+}$ and normalizes aberrant lipogenic/muscular commitment, eliminating lipid accumulation and recovering the muscular performance in blAJ mice [199]. These findings suggest that Cx and Panx hemichannels constitute a potential therapeutic target for the treatment of dysferlinopathies. In this regard, the use of boldine, a Cx/Panx-hemichannel blocker that does not affect gap junction channels [200] prevents muscle alterations induced by mutations in the DYSF gene [198].

There are other MDs in which the involvement of $C x$ and Panx hemichannels has not yet been explored. However, as described above, most MDs share non-specific pathological mechanisms including OS and chronic inflammation in which Cx and Panx hemichannels could participate. In support of this idea the use of boldine has been shown to reduce the ROS levels and inflammation signs in different pathologies [201,202].

\section{Pharmacological Therapies for MDs: Fight OS, Inflammation and Hemichannels Overexpression as a Potential Alternative}

Innovative therapeutic approaches, such as CRISPR/Cas systems and nanomedicine for drug repurposing, are in development for the treatment of MDs [203,204]. However, they are not available in the near future and may not be affordable for many patients. "Nutraceuticals" or functional foods have emerged in the last few years as an alternative to traditional medicine. These can be defined as a food or part of a food that provides health or medical benefits. A large number of nutraceuticals are thought to have anti-inflammatory and/or antioxidant effects [205]. Among them are resveratrol, coenzyme Q10 (CoQ10) and curcumin.

As chronic inflammation, OS and connexin de novo expression are pathological mechanisms that coexist in MDs, an effective therapy should consider the targeting of these three processes. In this regard, an interesting compound is resveratrol, a polyphenol that exhibits both antioxidative and anti-inflammatory properties, as well as inhibits Cx43 
hemichannels [191]. This polyphenol reportedly regulates the expression of different types of antioxidative and anti-inflammatory signaling proteins by inhibiting the NF-KB pathway [206,207]. It also activates sirtuin 1 [208], a NAD-dependent deacetylase that regulates transcription factors involved in muscle development, mass and metabolism [209]. In the skeletal muscle, resveratrol regulates the expression of genes involved in mitochondrial biogenesis [210,211], increasing aerobic capacity in mice [210]. Indeed, administration of $0.4 \mathrm{~g}$ resveratrol $/ \mathrm{kg}$ to $\mathrm{mdx}$ mice prevent mitochondria accumulation and reduced ROS levels [212,213]. This polyphenol further promotes skeletal muscle hypertrophy in wildtype mice [214] and attenuates, either by itself or in combination with exercise training, the skeletal muscle atrophy induced in different disease animal models [215-218], including DMD [219]. In mdx mice, it also reduces skeletal muscle necrosis and the expression of inflammatory markers [214]. As evaluated in a pilot randomized controlled trial in senior adults, it enhances the aerobic capacity and improves skeletal muscle mitochondrial function in combination with exercise [220]. Recently, an open-label, single-arm, phase-2 trial was performed with 11 patients with Duchenne, Becker, or Fukuyama MDs who received $500 \mathrm{mg}$ /day of resveratrol, a dose that was increased every 8 weeks to 1000 and $1500 \mathrm{mg} /$ day. After 24 weeks of treatment, motor function, muscular strength and creatine kinase levels significantly improved [221].

It is noteworthy that most of the studies in mdx mice showing that resveratrol improved the dystrophic pathology used doses ranged from 100-400 mg/Kg/day [216-219], which are 7 to 28 -fold higher than maximal doses used in human $[220,222]$. Only a recent study showed that a low dose of resveratrol $(5 \mathrm{mg} / \mathrm{Kg} /$ day) reduced exercise-induced skeletal muscle necrosis in mdx mice, as measured by inflammatory infiltrate, myofibres with fragmented sarcoplasm and areas of regenerating myofibres [214]. However, this low dose of resveratrol did not reduce necrosis in the quadriceps of sedentary mdx mice, nor did it increase skeletal muscle hypertrophy, as observed in wild-type mice. Serum creatin kinase activity was not reduced with low resveratrol doses in either sedentary or exercise mdx mice [214]. The latter authors proposed that low doses of resveratrol control exercise-induced inflammation by a signaling pathway different from that of sirtuin 1 [214]. Other studies show that resveratrol displays biphasic dose-dependent effects, exerting antioxidant properties at low concentrations, and increasing oxidative stress at high concentrations [223]. For instance, a low dose of resveratrol $(0.07 \mathrm{mg} / \mathrm{kg} /$ day $)$ inhibits adenoma development in mice more potently than a dose 200 -fold higher $(14 \mathrm{mg} / \mathrm{kg} /$ day) [224]. Therefore, it is necessary to determine how different doses of resveratrol can impact skeletal muscle function.

Another interesting compound is CoQ10. This is an electron carrier in mitochondrial electron-transport chain [225] and an efficient liposoluble antioxidant [226]. These two CoQ10 properties are beneficial for mitochondrial bioenergetics [227]. Meta-analysis of clinical trials indicates that CoQ10 supplementation increases the levels of total antioxidant capacity and antioxidant defense system enzymes [228,229]. In vitro studies in primary skeletal muscle cell cultures from mdx mice showed that CoQ10 reduced the OS and restored $\mathrm{Ca}^{2+}$ levels [230]. In a pilot trial in DMD patients treated with prednisone, CoQ10 showed to increase muscle strength [231]. Therefore, it could be another antioxidant agent that deserves further study in MDs. Furthermore, considering that it exhibits different properties than those described for resveratrol, the effectiveness of these two antioxidant agents could be potentiated when used in combination.

Curcumin is a chemical compound belonging to the group of curcuminoids, which are phenolic pigments produced by plants of the Curcuma longa species [232]. Curcumin presents anti-inflammatory and antioxidative properties [233], which seem to rely on its capability to inhibit the activation of NF-KB [234]. Combined with resveratrol, curcumin increases skeletal muscle mass in patients with chronic kidney disease [222]. Furthermore, curcumin has also been shown to significantly reduce the expression of $\mathrm{Cx} 43$ by promoting its degradation [197]. Curcumin has been studied in the context of DMD. In 2006 Durham and collaborators fed mdx mice with a $1 \%(w / w)$-curcumin-supplemented diet, showing 
an improvement in the muscle contractile properties (compared to mice fed with a control standard chow diet) [235]. Two years later, Pan et al. (2008) reported that the intraperitoneal injection of a higher dose of curcumin $(1 \mathrm{mg} / \mathrm{Kg})$ improved specific muscle strength as well as managed to suppress NFKB activation and to reduce the serum TNF- $\alpha$ and IL-1 $\beta$ levels in mdx mice [236]. These data suggest that supplementing the diet with curcumin could help to mitigate the inflammatory and dystrophic signs in DMD. As other neutraceuticals, including resveratrol, curcumin exhibits a very low bioavailability due to its fast metabolization in intestine and liver [237]. However, new delivery systems that improved drug solubility in oral formulations are in development [237].

\section{Concluding Remarks}

MDs are a group of diseases that initially affect mainly skeletal muscles and that are caused by mutations in genes encoding proteins essential for muscle structure and function. The absence or dysfunction of these proteins disturb the muscle integrity and/or homeostasis, provoking a cascade of events including inflammation, overexpression of nonselective channels such as $\mathrm{Cx}$ hemichannels, disruption of the ionic asymmetry across the sarcolemma, intracellular $\mathrm{Ca}^{2+}$ mishandling and activation of ROS-generating metabolic pathways. Among these latter is mitochondrial dysfunction, which importantly contributes to ROS generation, cell death and consequent muscle degeneration. The type of MD and the MD-causing mutation seem to be critical aspects defining which of these pathways happen first. However, the interaction between them might constitute a positive feedback loop that worsen the disease; therefore, the more advanced is the pathological state the more difficult seems to find a specific molecular target that could abrogate the progression of the disease. Up to now there is no cure for these ailments, yet gene therapy strategies that are in development will probably be accessible in the future. Therefore, the use of existing pharmacological therapies that can disrupt the interplay between these different cellular responses might help to slow down the progression of the muscle dystrophy. In this regard, nutraceuticals that interfere with the signaling pathways inducing OS, inflammation, mitochondria dysfunction or hemichannel activity might mitigate the progress of these diseases and improve the life quality of the patients. Among them, resveratrol, a polyphenol that inhibits the NF-KB pathway and Cx hemichannels, and displays antioxidant and antiinflammatory properties has shown promising results in clinical trials. However, additional studies are required to determine its optimal dose and treatment schedule.

Author Contributions: A.M.C. received the initial invitation to write a review on this topic; writing original draft preparation, A.G.-J., W.V., G.C.-R., R.M.-P., J.C.S. and A.M.C.; writing-review and editing, A.G.-J., J.C.S. and A.M.C. All authors have read and agreed to the published version of the manuscript.

Funding: This research was funded by grants 1191329 from ANID, Chile (to J.C.S.) and ACE210014 (to CINV) from ICM-ANID, Chile.

Institutional Review Board Statement: No applicable.

Informed Consent Statement: No applicable.

Data Availability Statement: No applicable.

Acknowledgments: We thank Felipe Serrano and his Company Ilustrative Science for the confection of Figure 1.

Conflicts of Interest: The authors declare no conflict of interest.

\section{References}

1. González-Jamett, A.M.; Bevilacqua, J.A.; Cárdenas Díaz, A.M. Hereditary Myopathies. In Muscle Cell and Tissue—Current Status of Research Field; Sakuma, K., Ed.; IntechOpen: London, UK, 2018. [CrossRef]

2. Silvestri, N.J.; Ismail, H.; Zimetbaum, P.; Raynor, E.M. Cardiac involvement in the muscular dystrophies. Muscle Nerve 2018, 57, 707-715. [CrossRef]

3. Mercuri, E.; Bönnemann, C.G.; Muntoni, F. Muscular dystrophies. Lancet 2019, 394, 2025-2038. [CrossRef] 
4. Zambon, A.A.; Muntoni, F. Congenital muscular dystrophies, What is new? Neuromuscul. Disord. 2021, 31, 931-942. [CrossRef] [PubMed]

5. Rossi, G.; Taglietti, V.; Messina, G. Targeting Nfix to fix muscular dystrophies. Cell Stress 2017, 2, 17-19. [CrossRef] [PubMed]

6. Mosca, N.; Petrillo, S.; Bortolani, S.; Monforte, M.; Ricci, E.; Piemonte, F.; Tasca, G. Redox Homeostasis in Muscular Dystrophies. Cells 2021, 10, 1364. [CrossRef] [PubMed]

7. Hooijmans, M.T.; Froeling, M.; Koeks, Z.; Verschuuren, J.J.G.M.; Webb, A.; Niks, E.H.; Kan, H.E. Multi-parametric MR in Becker muscular dystrophy patients. NMR Biomed. 2020, 33, e4385. [CrossRef]

8. Marozzo, R.; Pegoraro, V.; Angelini, C. MiRNAs, Myostatin, and Muscle MRI Imaging as Biomarkers of Clinical Features in Becker Muscular Dystrophy. Diagnostics 2020, 10, 713. [CrossRef] [PubMed]

9. Konkay, K.; Kannan, M.A.; Lingappa, L.; Uppin, M.S.; Challa, S. Congenital muscular dystrophy with inflammation, Diagnostic considerations. Ann. Indian Acad. Neurol. 2016, 19, 356-359. [PubMed]

10. Aksu-Menges, E.; Eylem, C.C.; Nemutlu, E.; Gizer, M.; Korkusuz, P.; Topaloglu, H.; Talim, B.; Balci-Hayta, B. Reduced mitochondrial fission and impaired energy metabolism in human primary skeletal muscle cells of Megaconial Congenital Muscular Dystrophy. Sci. Rep. 2021, 11, 18161. [CrossRef]

11. Mitsuhashi, S.; Ohkuma, A.; Talim, B.; Karahashi, M.; Koumura, T.; Aoyama, C.; Kurihara, M.; Quinlivan, R.; Sewry, C.; Mitsuhashi, H.; et al. A congenital muscular dystrophy with mitochondrial structural abnormalities caused by defective de novo phosphatidylcholine biosynthesis. Am. J. Hum. Genet. 2011, 88, 845-851. [CrossRef] [PubMed]

12. Angelin, A.; Bonaldo, P.; Bernardi, P. Altered threshold of the mitochondrial permeability transition pore in Ullrich congenital muscular dystrophy. Biochim. Biophys. Acta 2008, 1777, 893-896. [CrossRef]

13. Angelin, A.; Tiepolo, T.; Sabatelli, P.; Grumati, P.; Bergamin, N.; Golfieri, C.; Mattioli, E.; Gualandi, F.; Ferlini, A.; Merlini, L.; et al. Mitochondrial dysfunction in the pathogenesis of Ullrich congenital muscular dystrophy and prospective therapy with cyclosporins. Proc. Natl. Acad. Sci. USA 2007, 104, 991-996. [CrossRef] [PubMed]

14. Fontes-Oliveira, C.C.; Steinz, M.; Schneiderat, P.; Mulder, H.; Durbeej, M. Bioenergetic Impairment in Congenital Muscular Dystrophy Type 1A and Leigh Syndrome Muscle Cells. Sci. Rep. 2017, 7, 45272. [CrossRef] [PubMed]

15. Rowin, J.; Meriggioli, M.N.; Cochran, E.J.; Sanders, D.B. Prominent inflammatory changes on muscle biopsy in patients with Miyoshi myopathy. Neuromuscul. Disord. 1999, 9, 417-420. [CrossRef]

16. Cho, H.J.; Sung, D.H.; Kim, E.J.; Yoon, C.H.; Ki, C.S.; Kim, J.W. Clinical and genetic analysis of Korean patients with Miyoshi myopathy, identification of three novel mutations in the DYSF gene. J. Korean Med. Sci. 2006, 21, 724-727. [CrossRef] [PubMed]

17. Rodriguez, M.C.; Tarnopolsky, M.A. Patients with dystrophinopathy show evidence of increased oxidative stress. Free Radic. Biol. Med. 2003, 34, 1217-1220. [CrossRef]

18. Petrillo, S.; Pelosi, L.; Piemonte, F.; Travaglini, L.; Forcina, L.; Catteruccia, M.; Petrini, S.; Verardo, M.; D'Amico, A.; Musarò, A.; et al. Oxidative stress in Duchenne muscular dystrophy, focus on the NRF2 redox pathway. Hum. Mol. Genet. 2017, 26, 2781-2790. [CrossRef] [PubMed]

19. Almeida-Becerril, T.; Rodríguez-Cruz, M.; Raúl Sánchez-González, J.; Antonio Villaldama-Soriano, M.; Atilano-Miguel, S.; Villa-Morales, J.; Cárdenas-Conejo, A.; Cárdenas-Vázquez, R. Circulating markers of oxidative stress are associated with a muscle injury in patients with muscular dystrophy Duchenne. Brain Dev. 2021, 43, 111-120. [CrossRef] [PubMed]

20. Cruz-Guzmán, O. del R.; Rodríguez-Cruz, M.; Escobar Cedillo, R.E. Systemic Inflammation in Duchenne Muscular Dystrophy, Association with Muscle Function and Nutritional Status. Biomed. Res. Int. 2015, 2015, 891972. [CrossRef]

21. Piñol-Jurado, P.; Gallardo, E.; de Luna, N.; Suárez-Calvet, X.; Sánchez-Riera, C.; Fernández-Simón, E.; Gomis, C.; Illa, I.; DíazManera, J. Platelet-Derived Growth Factor BB Influences Muscle Regeneration in Duchenne Muscle Dystrophy. Am. J. Pathol. 2017, 187, 1814-1827. [CrossRef] [PubMed]

22. Scholte, H.R.; Busch, H.F. Early changes of muscle mitochondria in Duchenne dystrophy. Partition and activity of mitochondrial enzymes in fractionated muscle of unaffected boys and adults and patients. J. Neurol. Sci. 1980, 45, 217-234. [CrossRef]

23. Moore, T.M.; Lin, A.J.; Strumwasser, A.R.; Cory, K.; Whitney, K.; Ho, T.; Ho, T.; Lee, J.L.; Rucker, D.H.; Nguyen, C.Q.; et al. Mitochondrial Dysfunction Is an Early Consequence of Partial or Complete Dystrophin Loss in mdx Mice. Front. Physiol. 2020, 11, 690. [CrossRef]

24. Magagnotti, C.; Bachi, A.; Zerbini, G.; Fattore, E.; Fermo, I.; Riba, M.; Previtali, S.C.; Ferrari, M.; Andolfo, A.; Benedetti, S. Protein profiling reveals energy metabolism and cytoskeletal protein alterations in LMNA mutation carriers. Biochim. Biophys. Acta 2012, 1822, 970-979. [CrossRef]

25. Niebroj-Dobosz, I.; Sokołowska, B.; Madej-Pilarczyk, A.; Marchel, M.; Hausmanowa-Petrusewicz, I. Dysfunctional lamins as mediators of oxidative stress in Emery-Dreifuss muscular dystrophy. Folia Neuropathol. 2017, 55, 193-198. [CrossRef]

26. Turki, A.; Hayot, M.; Carnac, G.; Pillard, F.; Passerieux, E.; Bommart, S.; Raynaud de Mauverger, E.; Hugon, G.; Pincemail, J.; Pietri, S.; et al. Functional muscle impairment in facioscapulohumeral muscular dystrophy is correlated with oxidative stress and mitochondrial dysfunction. Free Radic. Biol. Med. 2012, 53, 1068-1079. [CrossRef]

27. Dhanarajan, R.; Patil, A.B.; Alexander, M.; Chacko, G.; Oommen, A. Degradation of myofibrillar proteins and inadequate antioxidants in selective muscle wasting of limb girdle muscular dystrophy. Int. J. Case Rep. Images 2011, 2, 6-11. [CrossRef]

28. Renjini, R.; Gayathri, N.; Nalini, A.; Srinivas Bharath, M. Oxidative damage in muscular dystrophy correlates with the severity of the pathology, Role of glutathione metabolism. Neurochem. Res. 2012, 37, 885-898. [CrossRef] 
29. Rajakumar, D.; Senguttuvan, S.; Alexander, M.; Oommen, A. Involvement of oxidative stress, nuclear factor kappa B and the ubiquitin proteasomal pathway in dysferlinopathy. Life Sci. 2014, 108, 54-61. [CrossRef]

30. Prosser, B.L.; Khairallah, R.J.; Ziman, A.P.; Ward, C.W.; Lederer, W.J. X-ROS signaling in the heart and skeletal muscle, Stretchdependent local ROS regulates [Ca ${ }^{2+}$ ]i. J. Mol. Cell. Cardiol. 2013, 58, 172-181. [CrossRef]

31. Kombairaju, P.; Kerr, J.P.; Roche, J.A.; Pratt, S.J.P.; Lovering, R.M.; Sussan, T.E.; Kim, J.H.; Shi, G.; Biswal, S.; Ward, C.W. Genetic silencing of Nrf2 enhances X-ROS in dysferlin-deficient muscle. Front. Physiol. 2014, 5, 57. [CrossRef]

32. Terrill, J.R.; Radley-Crabb, H.G.; Iwasaki, T.; Lemckert, F.A.; Arthur, P.G.; Grounds, M.D. Oxidative stress and pathology in muscular dystrophies, Focus on protein thiol oxidation and dysferlinopathies. FEBS J. 2013, 280, 4149-4164. [CrossRef]

33. García-Campos, P.; Báez-Matus, X.; Jara-Gutiérrez, C.; Paz-Araos, M.; Astorga, C.; Cea, L.A.; Rodríguez, V.; Bevilacqua, J.A.; Caviedes, P.; Cárdenas, A.M. N-Acetylcysteine Reduces Skeletal Muscles Oxidative Stress and Improves Grip Strength in Dysferlin-Deficient Bla/J Mice. Int. J. Mol. Sci. 2020, 21, 4293. [CrossRef] [PubMed]

34. Kramerova, I.; Kudryashova, E.; Wu, B.; Germain, S.; Vandenborne, K.; Romain, N.; Haller, R.G.; Verity, M.A.; Spencer, M.J. Mitochondrial abnormalities, energy deficit and oxidative stress are features of calpain 3 deficiency in skeletal muscle. Hum. Mol. Genet. 2009, 18, 3194-3205. [CrossRef] [PubMed]

35. Rawat, R.; Cohen, T.V.; Ampong, B.; Francia, D.; Henriques-Pons, A.; Hoffman, E.P.; Nagaraju, K. Inflammasome Up-Regulation and Activation in Dysferlin-Deficient Skeletal. Muscle. Am. J. Pathol. 2010, 176, 2891-2900. [CrossRef]

36. Verhaart, I.E.C.; Putker, K.; van de Vijver, D.; Tanganyika-de Winter, C.L.; Pasteuning-Vuhman, S.; Plomp, J.J.; Aartsma-Rus, A.M.; van Putten, M. Cross-sectional study into age-related pathology of mouse models for limb girdle muscular dystrophy types $2 \mathrm{D}$ and 2F. PLoS ONE 2019, 14, e0220665. [CrossRef] [PubMed]

37. Liu, F.; Lou, J.; Zhao, D.; Li, W.; Zhao, Y.; Sun, X.; Yan, C. Dysferlinopathy, mitochondrial abnormalities in human skeletal muscle Int. J. Neurosci. 2016, 126, 499-509. [CrossRef]

38. Koc, F.; Atli, G.; Menziletoglu, S.Y.; Kose, S. Antioxidant imbalance in the erythrocytes of Myotonic dystrophy Type 1 patients. Arch. Biochem. Biophys. 2020, 680, 108230. [CrossRef]

39. García-Puga, M.; Saenz-Antoñanzas, A.; Fernández-Torrón, R.; Munain, A.L.; Matheu, A. Myotonic Dystrophy type 1 cells display impaired metabolism and mitochondrial dysfunction that are reversed by metformin. Aging 2020, 12, 6260-6275. [CrossRef]

40. Vest, K.E.; Phillips, B.L.; Banerjee, A.; Apponi, L.H.; Dammer, E.B.; Xu, W.; Zheng, D.; Yu, J.; Tian, B.; Pavlath, G.K.; et al. Novel mouse models of oculopharyngeal muscular dystrophy (OPMD) reveal early onset mitochondrial defects and suggest loss of PABPN1 may contribute to pathology. Hum. Mol. Genet. 2017, 26, 3235-3252. [CrossRef]

41. Kiss, A.L. Inflammation in Focus, The Beginning and the End. Pathol. Oncol. Res. 2022, 27, 1610136. [CrossRef]

42. Castanheira, F.V.S.; Kubes, P. Neutrophils and NETs in modulating acute and chronic inflammation. Blood 2019, 133, 2178-2185. [CrossRef] [PubMed]

43. Mukund, K.; Subramaniam, S. Skeletal muscle, A review of molecular structure and function, in health and disease. Wiley Interdiscip. Rev. Syst. Biol. Med. 2020, 12, e1462. [CrossRef] [PubMed]

44. Henderson, C.A.; Gomez, C.G.; Novak, S.M.; Mi-Mi, L.; Gregorio, C.C. Overview of the Muscle Cytoskeleton. Compr. Physiol. 2017, 7, 891-944.

45. Hoppeler, H. Molecular networks in skeletal muscle plasticity. Exp. Biol. 2016, 219, 205-213. [CrossRef]

46. Yanay, N.; Rabie, M.; Nevo, Y. Impaired Regeneration in Dystrophic Muscle-New Target for Therapy. Front. Mol. Neurosci. 2020, $13,69$.

47. von Maltzahn, J.; Jones, A.E.; Parks, R.J.; Rudnicki, M.A. Pax7 is critical for the normal function of satellite cells in adult skeletal muscle. Proc. Natl. Acad. Sci. USA 2013, 110, 16474-16479. [CrossRef]

48. Yang, W.; Hu, P. Skeletal muscle regeneration is modulated by inflammation. J. Orthop. Translat. 2018, 13, 25-32. [CrossRef]

49. Frenette, J.; Cai, B. Tidball JG. Complement activation promotes muscle inflammation during modified muscle use. Am. J. Pathol. 2000, 156, 2103-2110. [CrossRef]

50. Saclier, M.; Yacoub-Youssef, H.; Mackey, A.L.; Arnold, L.; Ardjoune, H.; Magnan, M.; Sailhan, F.; Chelly, J.; Pavlath, G.K.; Mounier R.; et al. Differentially activated macrophages orchestrate myogenic precursor cell fate during human skeletal muscle regeneration. Stem Cells 2013, 31, 384-396. [CrossRef]

51. Arnold, L.; Henry, A.; Poron, F.; Baba-Amer, Y.; van Rooijen, N.; Plonquet, A.; Gherardi, R.K.; Chazaud, B. Inflammatory monocytes recruited after skeletal muscle injury switch into antiinflammatory macrophages to support myogenesis. J. Exp. Med. 2007, 204, 1057-1069. [CrossRef]

52. Hoene, M.; Runge, H.; Häring, H.U.; Schleicher, E.D.; Weigert, C. Interleukin-6 promotes myogenic differentiation of mouse skeletal muscle cells, role of the STAT3 pathway. Am. J. Physiol. Cell. Physiol. 2013, 304, C128-C136. [CrossRef]

53. O'Leary, M.F.; Wallace, G.R.; Bennett, A.J.; Tsintzas, K.; Jones, S.W. IL-15 promotes human myogenesis and mitigates the detrimental effects of TNF $\alpha$ on myotube development. Sci. Rep. 2017, 7, 12997. [CrossRef] [PubMed]

54. Schiaffin, S.; Pereira, M.G.; Ciciliot, S.; Rovere-Querini, P. Regulatory T cells and skeletal muscle regeneration. FEBS J. 2017, 284, 517-524. [CrossRef]

55. Minari, A.L.; Oyama, L.M.; Dos Santos, R.V. Downhill exercise-induced changes in gene expression related with macrophage polarization and myogenic cells in the triceps long head of rats. Inflammation 2015, 38, 209-217. [CrossRef] 
56. Nagata, E.; Masuda, H.; Nakayama, T.; Netsu, S.; Yuzawa, H.; Fujii, N.; Kohara, S.; Sorimachi, T.; Osada, T.; Imazeki, R.; et al. Insufficient production of IL-10 from M2 macrophages impairs in vitro endothelial progenitor cell differentiation in patients with Moyamoya disease. Sci. Rep. 2019, 9, 16752. [CrossRef] [PubMed]

57. Costamagna, D.; Duelen, R.; Penna, F.; Neumann, D.; Costelli, P.; Sampaolesi, M. Interleukin-4 administration improves muscle function, adult myogenesis, and lifespan of colon carcinoma-bearing mice. J. Cachexia Sarcopenia Muscle 2020, 11, 783-801. [CrossRef]

58. Theret, M.; Saclier, M.; Messina, G.; Rossi, F.M.V. Macrophages in Skeletal Muscle Dystrophies: An Entangled Partner. J. Neuromuscul. Dis. 2022, 9, 1-23. [CrossRef] [PubMed]

59. Boursereau, R.; Abou-Samra, M.; Lecompte, S.; Noel, L.; Brichard, S.M. Downregulation of the NLRP3 inflammasome by adiponectin rescues Duchenne muscular dystrophy. BMC Biol. 2018, 16, 33. [CrossRef] [PubMed]

60. Gawlik, K.I.; Holmberg, J.; Svensson, M.; Einerborg, M.; Oliveira, B.M.; Deierborg, T.; Durbeej, M. Potent pro-inflammatory and pro-fibrotic molecules, osteopontin and galectin-3, are not major disease modulators of laminin $\alpha 2$ chain-deficient muscular dystrophy. Sci. Rep. 2017, 7, 44059. [CrossRef] [PubMed]

61. Cappelletti, C.; Salerno, F.; Canioni, E.; Mora, M.; Mantegazza, R.; Bernasconi, P.; Maggi, L. Up-regulation of Toll-like receptors 7 and 9 and its potential implications in the pathogenic mechanisms of LMNA-related myopathies. Nucleus 2018, 9, 398-409. [CrossRef] [PubMed]

62. Nalbandian, A.; Khan, A.A.; Srivastava, R.; Llewellyn, K.J.; Tan, B.; Shukr, N.; Fazli, Y.; Kimonis, V.E.; BenMohamed, L. Activation of the NLRP3 Inflammasome Is Associated with Valosin-Containing Protein Myopathy. Inflammation 2017, 40, 21-41. [CrossRef] [PubMed]

63. Tanboon, J.; Uruha, A.; Arahata, Y.; Dittmayer, C.; Schweizer, L.; Goebel, H.H.; Nishino, I.; Stenzel, W. Inflammatory features in sporadic late-onset nemaline myopathy are independent from monoclonal gammopathy. Brain Pathol. 2021, 31, e12962. [CrossRef]

64. Mah, J.K.; Korngut, L.; Dykeman, J.; Day, L.; Pringsheim, T.; Jette, N. A systematic review and meta-analysis on the epidemiology of Duchenne and Becker muscular dystrophy. Neuromuscul. Disord. 2014, 24, 482-491. [CrossRef] [PubMed]

65. Belhasan, D.C.; Akaaboune, M. The role of the dystrophin glycoprotein complex on the neuromuscular system. Neurosci. Lett. 2020, 722, 134833. [CrossRef] [PubMed]

66. Duan, D.; Goemans, N.; Takeda, S.; Mercuri, E.; Aartsma-Rus, A. Duchenne muscular dystrophy. Nat. Rev. Dis. Primers. 2021, 7, 13. [CrossRef] [PubMed]

67. Morgan, J.E.; Prola, A.; Mariot, V.; Pini, V.; Meng, J.; Hourde, C.; Dumonceaux, J.; Conti, F.; Relaix, F.; Authier, F.J.; et al Necroptosis mediates myofibre death in dystrophin-deficient mice. Nat. Commun. 2018, 9, 3655. [CrossRef]

68. Petrof, B.J.; Shrager, J.B.; Stedman, H.H.; Kelly, A.M.; Sweeney, H.L. Dystrophin protects the sarcolemma from stresses developed during muscle contraction. Proc. Natl. Acad. Sci. USA 1993, 90, 3710-3714. [CrossRef] [PubMed]

69. Sun, C.C.; Li, S.J.; Yang, C.L.; Xue, R.L.; Xi, Y.Y.; Wang, L.; Zhao, Q.L.; Li, D.J. Sulforaphane attenuates muscle inflammation in dystrophin-deficient mdx mice via NF-E2-related factor 2 (Nrf2)-mediated inhibition of NF-kB signaling pathway. J. Biol. Chem. 2015, 290, 17784-17795. [CrossRef] [PubMed]

70. Andrews, J.G.; Wahl, R.A. Duchenne and Becker muscular dystrophy in adolescents, current perspectives. Adolesc. Health Med. Ther. 2018, 9, 53-63. [CrossRef]

71. Fiorillo, A.A.; Heier, C.R.; Novak, J.S.; Tully, C.B.; Brown, K.J.; Uaesoontrachoon, K.; Vila, M.C.; Ngheim, P.P.; Bello, L.; Kornegay, J.N.; et al. TNF- $\alpha$-Induced microRNAs Control Dystrophin Expression in Becker Muscular Dystrophy. Cell Rep. 2015, 12, 1678-1690. [CrossRef]

72. Aartsma-Rus, A.; Ginjaar, I.B.; Bushby, K. The importance of genetic diagnosis for Duchenne muscular dystrophy. J. Med. Genet. 2016, 53, 145-151. [CrossRef]

73. Preuße, C.; von Moers, A.; Kölbel, H.; Pehl, D.; Goebel, H.H.; Schara, U.; Stenzel, W. Inflammation-induced fibrosis in skeletal muscle of female carriers of Duchenne muscular dystrophy. Neuromuscul. Disord. 2019, 29, 487-496. [CrossRef] [PubMed]

74. Hammers, D.W.; Sleeper, M.M.; Forbes, S.C.; Coker, C.C.; Jirousek, M.R.; Zimmer, M.; Walter, G.A.; Sweeney, H.L. Diseasemodifying effects of orally bioavailable NF- $\mathrm{kB}$ inhibitors in dystrophin-deficient muscle. JCI Insight. 2016, 1, e90341. [CrossRef] [PubMed]

75. Carvalho, S.C.; Apolinário, L.M.; Matheus, S.M.; Santo Neto, H.; Marques, M.J. EPA protects against muscle damage in the mdx mouse model of Duchenne muscular dystrophy by promoting a shift from the M1 to M2 macrophage phenotype. J. Neuroimmunol. 2013, 264, 41-47. [CrossRef] [PubMed]

76. Rodríguez-Cruz, M.; Cruz-Guzmán, O.D.R.; Almeida-Becerril, T.; Solís-Serna, A.D.; Atilano-Miguel, S.; Sánchez-González, J.R.; Barbosa-Cortés, L.; Ruíz-Cruz, E.D.; Huicochea, J.C.; Cárdenas-Conejo, A.; et al. Potential therapeutic impact of omega-3 long chain-polyunsaturated fatty acids on inflammation markers in Duchenne muscular dystrophy, A double-blind, controlled randomized trial. Clin. Nutr. 2018, 37, 1840-1851. [CrossRef]

77. Rodríguez-Cruz, M.; Atilano-Miguel, S.; Barbosa-Cortés, L.; Bernabé-García, M.; Almeida-Becerril, T.; Cárdenas-Conejo, A.; del Rocío Cruz-Guzmán, O.; Maldonado-Hernández, J. Evidence of muscle loss delay and improvement of hyperinsulinemia and insulin resistance in Duchenne muscular dystrophy supplemented with omega-3 fatty acids, A randomized study. Clin. Nutr. 2019, 38, 2087-2097. [CrossRef] 
78. Vita, G.L.; Sframeli, M.; Licata, N.; Bitto, A.; Romeo, S.; Frisone, F.; Ciranni, A.; Pallio, G.; Mannino, F.; Aguennouz, M.H.; et al. A Phase 1/2 Study of Flavocoxid, an Oral NF-кB Inhibitor, in Duchenne Muscular Dystrophy. Brain Sci. 2021, 11, 115. [CrossRef] [PubMed]

79. Finkel, R.S.; Finanger, E.; Vandenborne, K.; Sweeney, H.L.; Tennekoon, G.; Shieh, P.B.; Willcocks, R.; Walter, G.; Rooney, W.D.; Forbes, S.C.; et al. Disease-modifying effects of edasalonexent, an NF- $\mathrm{kB}$ inhibitor, in young boys with Duchenne muscular dystrophy, Results of the MoveDMD phase 2 and open label extension trial. Neuromuscul. Disord. 2021, 31, 385-396. [CrossRef]

80. Finkel, R.S.; McDonald, C.M.; Lee Sweeney, H.; Finanger, E.; Neil Knierbein, E.; Wagner, K.R.; Mathews, K.D.; Marks, W.; Statland, J.; Nance, J.; et al. A Randomized, Double-Blind, Placebo-Controlled, Global Phase 3 Study of Edasalonexent in Pediatric Patients with Duchenne Muscular Dystrophy, Results of the PolarisDMD Trial. J. Neuromuscul. Dis. 2021, 8, 769-784. [CrossRef] [PubMed]

81. Péladeau, C.; Sandhu, J.K. Aberrant NLRP3 Inflammasome Activation Ignites the Fire of Inflammation in Neuromuscular Diseases. Int. J. Mol. Sci. 2021, 22, 6068. [CrossRef] [PubMed]

82. Kelley, N.; Jeltema, D.; Duan, Y.; He, Y. The NLRP3 Inflammasome: An Overview of Mechanisms of Activation and Regulation. Int. J. Mol. Sci. 2019, 20, 3328.

83. Jung, H.N.; Jung, C.H. The Role of Anti-Inflammatory Adipokines in Cardiometabolic Disorders, Moving beyond Adiponectin. Int. J. Mol. Sci. 2021, 22, 13529. [CrossRef] [PubMed]

84. Abou-Samra, M.; Lecompte, S.; Schakman, O.; Noel, L.; Many, M.C.; Gailly, P.; Brichard, S.M. Involvement of adiponectin in the pathogenesis of dystrophinopathy. Skelet. Muscle 2015, 5, 25. [CrossRef]

85. Abou-Samra, M.; Boursereau, R.; Lecompte, S.; Noel, L.; Brichard, S.M. Potential Therapeutic Action of Adiponectin in Duchenne Muscular Dystrophy. Am. J. Pathol. 2017, 187, 1577-1585. [CrossRef] [PubMed]

86. Abou-Samra, M.; Selvais, C.M.; Boursereau, R.; Lecompte, S.; Noel, L.; Brichard, S.M. AdipoRon, a new therapeutic prospect for Duchenne muscular dystrophy. J. Cachexia Sarcopenia Muscle 2020, 11, 518-533. [CrossRef] [PubMed]

87. Chang, L.; Niu, F.; Chen, J.; Cao, X.; Liu, Z.; Bao, X.; Xu, Y. Ghrelin improves muscle function in dystrophin-deficient mdx mice by inhibiting NLRP3 inflammasome activation. Life Sci. 2019, 232, 116654. [CrossRef] [PubMed]

88. Lamandé, S.R. Collagen VI Muscle Disorders, Mutation Types, Pathogenic Mechanisms and Approaches to Therapy. Adv. Exp. Med. Biol. 2021, 1348, 311-323.

89. Mehuron, T.; Kumar, A.; Duarte, L.; Yamauchi, J.; Accorsi, A.; Girgenrath, M. Dysregulation of matricellular proteins is an early signature of pathology in laminin-deficient muscular dystrophy. Skelet. Muscle 2014, 4, 14. [CrossRef] [PubMed]

90. Heller, S.A.; Shih, R.; Kalra, R.; Kang, P.B. Emery-Dreifuss muscular dystrophy. Muscle Nerve 2020, 61, 436-448.

91. Tarakci, H.; Berger, J. The sarcoglycan complex in skeletal muscle. Front. Biosci 2016, 21, 744-756.

92. Pradhan, B.S.; Prószyński, T.J. A Role for Caveolin-3 in the Pathogenesis of Muscular Dystrophies. Int. J. Mol. Sci. 2020, 21, 8736. [CrossRef] [PubMed]

93. Ono, Y.; Ojima, K.; Shinkai-Ouchi, F.; Hata, S.; Sorimachi, H. An eccentric calpain, CAPN3/p94/calpain-3. Biochimie 2016, 122, 169-187. [CrossRef]

94. Eiber, N.; Fröb, F.; Schowalter, M.; Thiel, C.; Clemen, C.S.; Schröder, R.; Hashemolhosseini, S. Lack of Desmin in Mice Causes Structural and Functional Disorders of Neuromuscular Junctions. Front. Mol. Neurosci. 2020, 13, 567084. [CrossRef]

95. Freundt, J.K.; Linke, W.A. Titin as a force-generating muscle protein under regulatory control. J. Appl. Physiol. 2019, 126, 1474-1482. [CrossRef]

96. Cárdenas, A.M.; González-Jamett, A.M.; Cea, L.A.; Bevilacqua, J.A.; Caviedes, P. Dysferlin function in skeletal muscle, Possible pathological mechanisms and therapeutical targets in dysferlinopathies. Exp. Neurol. 2016, 283, 246-254. [CrossRef]

97. Defour, A.; Medikayala, S.; Van der Meulen, J.; Hogarth, M.; Holdreith, N.; Malatras, A.; Duddy, W.; Boehler, J.; Nagaraju, K.; Jaiswal, J.K. Annexin A2 links poor myofiber repair with inflammation and adipogenic replacement of the injured muscle. Hum. Mol. Genet. 2017, 26, 1979-1991. [CrossRef]

98. Lostal, W.; Bartoli, M.; Roudaut, C.; Bourg, N.; Krahn, M.; Pryadkina, M.; Borel, P.; Suel, L.; Roche, J.A.; Stockholm, D.; et al. Lack of correlation between outcomes of membrane repair assay and correction of dystrophic changes in experimental therapeutic strategy in dysferlinopathy. PLOS ONE 2012, 7, e38036. [CrossRef]

99. Bittel, D.C.; Chandra, G.; Tirunagri, L.M.S.; Deora, A.B.; Medikayala, S.; Scheffer, L.; Defour, A.; Jaiswal, J.K. Annexin A2 Mediates Dysferlin Accumulation and Muscle Cell Membrane Repair. Cells. 2020, 9, 1919. [CrossRef]

100. Báez-Matus, X.; Figueroa-Cares, C.; Gónzalez-Jamett, A.M.; Almarza-Salazar, H.; Arriagada, C.; Maldifassi, M.C.; Guerra, M.J.; Mouly, V.; Bigot, A.; Caviedes, P.; et al. Defects in G-Actin Incorporation into Filaments in Myoblasts Derived from Dysferlinopathy Patients Are Restored by Dysferlin C2 Domains. Int. J. Mol. Sci. 2019, 21, 37. [CrossRef]

101. Leung, C.; Utokaparch, S.; Sharma, A.; Yu, C.; Abraham, T.; Borchers, C.; Bernatchez, P. Proteomic identification of dysferlininteracting protein complexes in human vascular endothelium. Biochem. Biophys. Res. Commun. 2011, 415, 263-269. [CrossRef]

102. Yin, X.; Wang, Q.; Chen, T.; Niu, J.; Ban, R.; Liu, J.; Mao, Y.; Pu, C. CD4+ cells, macrophages, MHC-I and C5b-9 involve the pathogenesis of dysferlinopathy. Int. J. Clin. Exp. Pathol. 2015, 8, 3069-3075. [PubMed]

103. Baek, J.H.; Many, G.M.; Evesson, F.J.; Kelley, V.R. Dysferlinopathy Promotes an Intramuscle Expansion of Macrophages with a Cyto-Destructive Phenotype. Am. J. Pathol. 2017, 187, 1245-1257. [CrossRef] [PubMed]

104. Uaesoontrachoon, K.; Cha, H.; Ampong, B.; Sali, A.; Vandermeulen, J.; Wei, B.; Creeden, B.; Huynh, T.; Quinn, J.; Tatem, K.; et al The effects of MyD88 deficiency on disease phenotype in dysferlin-deficient A/J mice, role of endogenous TLR ligands. J. Pathol. 2013, 231, 199-209. [CrossRef] 
105. Powers, S.K.; Deminice, R.; Ozdemir, M.; Yoshihara, T.; Bomkamp, M.P.; Hyatt, H. Exercise-induced oxidative stress, Friend or foe? J. Sport Health Sci. 2020, 9, 415-425. [CrossRef]

106. Pang, B.P.S.; Chan, W.S.; Chan, C.B. Mitochondria Homeostasis and Oxidant/Antioxidant Balance in Skeletal Muscle-Do Myokines Play a Role? Antioxidants 2021, 10, 179. [CrossRef] [PubMed]

107. Xu, H.; Li, C.; Mozziconacci, O.; Zhu, R.; Xu, Y.; Tang, Y.; Chen, R.; Huang, Y.; Holzbeierlein, J.M.; Schöneich, C.; et al. Xanthine oxidase-mediated oxidative stress promotes cancer cell-specific apoptosis. Free Radic. Biol. Med. 2019, 139, 70-79. [CrossRef]

108. Su, L.J.; Zhang, J.H.; Gomez, H.; Murugan, R.; Hong, X.; Xu, D.; Jiang, F.; Peng, Z.Y. Reactive Oxygen Species-Induced Lipid Peroxidation in Apoptosis, Autophagy, and Ferroptosis. Oxid. Med. Cell. Longev. 2019, 2019, 5080843. [CrossRef]

109. Schröder, K. NADPH oxidase-derived reactive oxygen species, Dosis facit venenum. Exp. Physiol. 2019, 104, 447-452. [CrossRef]

110. Bouviere, J.; Fortunato, R.S.; Dupuy, C.; Werneck-de-Castro, J.P.; Carvalho, D.P.; Louzada, R.A. Exercise-Stimulated ROS Sensitive Signaling Pathways in Skeletal Muscle. Antioxidants 2021, 10, 537. [CrossRef]

111. Espinosa, A.; Leiva, A.; Peña, M.; Müller, M.; Debandi, A.; Hidalgo, C.; Carrasco, M.A.; Jaimovich, E. Myotube depolarization generates reactive oxygen species through $\mathrm{NAD}(\mathrm{P}) \mathrm{H}$ oxidase; ROS-elicited $\mathrm{Ca}^{2+}$ stimulates ERK, CREB, early genes. J. Cell. Physiol. 2006, 209, 379-388. [CrossRef]

112. Díaz-Vegas, A.; Campos, C.A.; Contreras-Ferrat, A.; Casas, M.; Buvinic, S.; Jaimovich, E.; Espinosa, A. ROS Production via P2Y1-PKC-NOX2 Is Triggered by Extracellular ATP after Electrical Stimulation of Skeletal Muscle Cells. PLoS ONE 2015, 10, e0129882. [CrossRef] [PubMed]

113. Jaque-Fernández, F.; Jorquera, G.; Troc-Gajardo, J.; Pietri-Rouxel, F.; Gentil, C.; Buvinic, S.; Allard, B.; Jaimovich, E.; Jacquemond, V.; Casas, M. Pannexin-1 and CaV1.1 show reciprocal interaction during excitation-contraction and excitation-transcription coupling in skeletal muscle. J. Gen. Physiol. 2021, 153, e202012635. [CrossRef] [PubMed]

114. Espinosa, A.; García, A.; Härtel, S.; Hidalgo, C.; Jaimovich, E. NADPH oxidase and hydrogen peroxide mediate insulin-induced calcium increase in skeletal muscle cells. J. Biol. Chem. 2009, 284, 2568-2575. [CrossRef] [PubMed]

115. Contreras-Ferrat, A.; Llanos, P.; Vásquez, C.; Espinosa, A.; Osorio-Fuentealba, C.; Arias-Calderon, M.; Lavandero, S.; Klip, A.; Hidalgo, C.; Jaimovich, E. Insulin elicits a ROS-activated and an IP3-dependent $\mathrm{Ca}^{2+}$ release, which both impinge on GLUT4 translocation. J. Cell. Sci. 2014, 127, 1911-1923. [PubMed]

116. Henríquez-Olguin, C.; Knudsen, J.R.; Raun, S.H.; Li, Z.; Dalbram, E.; Treebak, J.T.; Sylow, L.; Holmdahl, R.; Richter, E.A.; Jaimovich, E.; et al. Cytosolic ROS production by NADPH oxidase 2 regulates muscle glucose uptake during exercise. Nat. Commun. 2019, 10, 4623. [CrossRef]

117. Zisman, A.; Peroni, O.D.; Abel, E.D.; Michael, M.D.; Mauvais-Jarvis, F.; Lowell, B.B.; Wojtaszewski, J.F.; Hirshman, M.F.; Virkamaki, A.; Goodyear, L.J.; et al. Targeted disruption of the glucose transporter 4 selectively in muscle causes insulin resistance and glucose intolerance. Nat. Med. 2000, 6, 924-928. [CrossRef]

118. Taherkhani, S.; Valaei, K.; Arazi, H.; Suzuki, K. An Overview of Physical Exercise and Antioxidant Supplementation Influences on Skeletal Muscle Oxidative Stress. Antioxidants 2021, 10, 1528. [CrossRef]

119. Sylow, L.; Nielsen, I.L.; Kleinert, M.; Møller, L.L.V.; Ploug, T.; Schjerling, P.; Bilan, P.J.; Klip, A.; Jensen, T.E.; Richter, E.A. Rac1 governs exercise-stimulated glucose uptake in skeletal muscle through regulation of GLUT4 translocation in mice. J. Physiol. 2016, 594, 4997-5008. [CrossRef]

120. Wang, F.; Wang, X.; Liu, Y.; Zhang, Z. Effects of Exercise-Induced ROS on the Pathophysiological Functions of Skeletal Muscle. Oxid. Med. Cell. Longev. 2021, 2021, 3846122. [CrossRef]

121. Yan, X.; Shen, Z.; Yu, D.; Zhao, C.; Zou, H.; Ma, B.; Dong, W.; Chen, W.; Huang, D.; Yu, Z. Nrf2 contributes to the benefits of exercise interventions on age-related skeletal muscle disorder via regulating Drp1 stability and mitochondrial fission. Free Radic. Biol. Med. 2022, 178, 59-75. [CrossRef]

122. Hood, D.A.; Memme, J.M.; Oliveira, A.N.; Triolo, M. Maintenance of Skeletal Muscle Mitochondria in Health, Exercise, and Aging. Annu. Rev. Physiol. 2019, 81, 19-41. [CrossRef] [PubMed]

123. Fernández-Puente, E.; Palomero, J. Genetically Encoded Biosensors to Monitor Intracellular Reactive Oxygen and Nitrogen Species and Glutathione Redox Potential in Skeletal Muscle Cells. Int. J. Mol. Sci. 2021, 22, 10876. [CrossRef] [PubMed]

124. Kellogg, D.L., 3rd; McCammon, K.M.; Hinchee-Rodriguez, K.S.; Adamo, M.L.; Roman, L.J. Neuronal nitric oxide synthase mediates insulin- and oxidative stress-induced glucose uptake in skeletal muscle myotubes. Free Radic. Biol. Med. 2017, 110, 261-269. [CrossRef] [PubMed]

125. Thomas, G.D.; Victor, R.G. Nitric oxide mediates contraction-induced attenuation of sympathetic vasoconstriction in rat skeletal muscle. J. Physiol. 1998, 506, 817-826. [CrossRef] [PubMed]

126. Hong, Y.H.; Yang, C.; Betik, A.C.; Lee-Young, R.S.; McConell, G.K. Skeletal muscle glucose uptake during treadmill exercise in neuronal nitric oxide synthase- $\mu$ knockout mice. Am. J. Physiol. Endocrinol. Metab. 2016, 310, E838-E845. [CrossRef] [PubMed]

127. Martínez, M.C.; Andriantsitohaina, R. Reactive nitrogen species, molecular mechanisms and potential significance in health and disease. Antioxid. Redox. Signal. 2009, 11, 669-702. [CrossRef]

128. Foreman, N.A.; Hesse, A.S.; Ji, L.L. Redox Signaling and Sarcopenia, Searching for the Primary Suspect. Int. J. Mol. Sci. 2021, 22, 9045. [CrossRef]

129. Thomas, C.; Mackey, M.M.; Diaz, A.A.; Cox, D.P. Hydroxyl radical is produced via the Fenton reaction in submitochondrial particles under oxidative stress, implications for diseases associated with iron accumulation. Redox. Rep. 2009, 14, 102-108. [CrossRef] 
130. Roots, R.; Okada, S. Estimation of life times and diffusion distances of radicals involved in X-ray-induced DNA strand breaks or killing of mammalian cells. Radiat. Res. 1975, 64, 306-320. [CrossRef]

131. Le Moal, E.; Pialoux, V.; Juban, G.; Groussard, C.; Zouhal, H.; Chazaud, B.; Mounier, R. Redox Control of Skeletal Muscle Regeneration. Antioxid. Redox. Signal. 2017, 2, 276-310. [CrossRef]

132. Shi, Y.; Nikulenkov, F.; Zawacka-Pankau, J.; Li, H.; Gabdoulline, R.; Xu, J.; Eriksson, S.; Hedström, E.; Issaeva, N.; Kel, A.; et al ROS-dependent activation of JNK converts p53 into an efficient inhibitor of oncogenes leading to robust apoptosis. Cell. Death Differ. 2014, 21, 612-623. [CrossRef]

133. He, L.; He, T.; Farrar, S.; Ji, L.; Liu, T.; Ma, X. Antioxidants Maintain Cellular Redox Homeostasis by Elimination of Reactive Oxygen Species. Cell. Physiol. Biochem. 2017, 44, 532-553. [CrossRef] [PubMed]

134. Liu, T.; Zhang, L.; Joo, D.; Sun, S.C. NF-kappaB signaling in inflammation. Signal. Transduct. Target Ther. $2017,2,17023$. [CrossRef] [PubMed]

135. Fan, Y.; Tan, D.; Zhang, X.; Song, D.; Chang, X.; Wang, S.; Yan, H.; Ge, L.; Yang, H.; Bönnemann, C.; et al. Nuclear Factor-kB Pathway Mediates the Molecular Pathogenesis of LMNA-Related Muscular Dystrophies. Biochem. Genet. 2020, 58, 966-980. [CrossRef] [PubMed]

136. Lingappan, K. NF-kappaB in Oxidative Stress. Curr. Opin. Toxicol. 2018, 7, 81-86. [CrossRef]

137. Kitaoka, Y. The Role of Nrf2 in Skeletal Muscle on Exercise Capacity. Antioxidants 2021, 10, 1712. [CrossRef]

138. Anderson, E.J.; Neufer, P.D. Type II skeletal myofibers possess unique properties that potentiate mitochondrial $\mathrm{H}(2) \mathrm{O}(2)$ generation. Am. J. Physiol. Cell. Physiol. 2006, 290, C844-C851. [CrossRef]

139. St-Pierre, J.; Buckingham, J.A.; Roebuck, S.J.; Brand, M.D. Topology of superoxide production from different sites in the mitochondrial electron transport chain. J. Biol. Chem. 2002, 277, 44784-44790. [CrossRef]

140. Damiano, S.; Sozio, C.; La Rosa, G.; Guida, B.; Faraonio, R.; Santillo, M.; Mondola, P. Metabolism Regulation and Redox State, Insight into the Role of Superoxide Dismutase 1. Int. J. Mol. Sci. 2020, 21, 6606. [CrossRef]

141. Shkryl, V.M.; Martins, A.S.; Ullrich, N.D.; Nowycky, M.C.; Niggli, E.; Shirokova, N. Reciprocal amplification of ROS and Ca ${ }^{2+}$ signals in stressed mdx dystrophic skeletal muscle fibers. Pflugers Arch. 2009, 458, 915-928. [CrossRef]

142. Baughman, J.M.; Perocchi, F.; Girgis, H.S.; Plovanich, M.; Belcher-Timme, C.A.; Sancak, Y.; Bao, X.R.; Strittmatter, L.; Goldberger, O.; Bogorad, R.L.; et al. Integrative genomics identifies MCU as an essential component of the mitochondrial calcium uniporter. Nature 2011, 476, 341-345. [CrossRef]

143. Denton, R.M. Regulation of mitochondrial dehydrogenases by calcium ions. Biochim. Biophys. Acta 2009, 1787, 1309-1316. [CrossRef]

144. Briston, T.; Roberts, M.; Lewis, S.; Powney, B.; Staddon, J.M.; Szabadkai, G.; Duchen, M.R. Mitochondrial permeability transition pore, sensitivity to opening and mechanistic dependence on substrate availability. Sci. Rep. 2017, 7, 10492. [CrossRef] [PubMed]

145. Neginskaya, M.A.; Pavlov, E.V.; Sheu, S.S. Electrophysiological properties of the mitochondrial permeability transition pores, Channel diversity and disease implication. Biochim. Biophys. Acta Bioenerg. 2021, 1862, 148357. [CrossRef]

146. Zhou, H.; Toan, S. Pathological Roles of Mitochondrial Oxidative Stress and Mitochondrial Dynamics in Cardiac Microvascular Ischemia/Reperfusion Injury. Biomolecules 2020, 10, 85. [CrossRef] [PubMed]

147. Schill, K.E.; Altenberger, A.R.; Lowe, J.; Periasamy, M.; Villamena, F.A.; Rafael-Fortney, J.A.; Devor, S.T. Muscle damage, metabolism, and oxidative stress in mdx mice, Impact of aerobic running. Muscle Nerve 2016, 54, 110-117. [CrossRef] [PubMed]

148. Terrill, J.R.; Duong, M.N.; Turner, R.; Le Guiner, C.; Boyatzis, A.; Kettle, A.J.; Grounds, M.D.; Arthur, P.G. Levels of inflammation and oxidative stress, and a role for taurine in dystropathology of the Golden Retriever Muscular Dystrophy dog model for Duchenne Muscular Dystrophy. Redox. Biol. 2016, 9, 276-286. [CrossRef] [PubMed]

149. Mareedu, S.; Million, E.D.; Duan, D.; Babu, G.J. Abnormal Calcium Handling in Duchenne Muscular Dystrophy, Mechanisms and Potential Therapies. Front. Physiol. 2021, 12, 647010. [CrossRef] [PubMed]

150. Zabłocka, B.; Górecki, D.C.; Zabłocki, K. Disrupted Calcium Homeostasis in Duchenne Muscular Dystrophy, A Common Mechanism behind Diverse Consequences. Int. J. Mol. Sci. 2021, 22, 11040. [CrossRef]

151. Cea, L.A.; Puebla, C.; Cisterna, B.A.; Escamilla, R.; Vargas, A.A.; Frank, M.; Martínez-Montero, P.; Prior, C.; Molano, J.; Esteban-Rodríguez, I.; et al. Fast skeletal myofibers of mdx mouse, model of Duchenne muscular dystrophy, express connexin hemichannels that lead to apoptosis. Cell. Mol. Life Sci. 2016, 73, 2583-2599. [CrossRef]

152. Cea, L.A.; Bevilacqua, J.A.; Arriagada, C.; Cárdenas, A.M.; Bigot, A.; Mouly, V.; Sáez, J.C.; Caviedes, P. The absence of dysferlin induces the expression of functional connexin-based hemichannels in human myotubes. BMC Cell. Biol. 2016, 17, 15. [CrossRef] [PubMed]

153. Hempel, N.; Trebak, M. Crosstalk between calcium and reactive oxygen species signaling in cancer. Cell. Calcium 2017, 63, 70-96. [CrossRef] [PubMed]

154. Cully, T.R.; Rodney, G.G. Nox4-RyR1-Nox2, Regulators of micro-domain signaling in skeletal muscle. Redox. Biol. 2020, 36, 101557. [CrossRef] [PubMed]

155. Sieprath, T.; Corne, T.D.; Nooteboom, M.; Grootaert, C.; Rajkovic, A.; Buysschaert, B.; Robijns, J.; Broers, J.V.; Ramaekers, F.C.; Koopman, W.J.; et al. Sustained accumulation of prelamin A and depletion of lamin A/C both cause oxidative stress and mitochondrial dysfunction but induce different cell fates. Nucleus 2015, 6, 236-246. [CrossRef] [PubMed]

156. Pekovic, V.; Gibbs-Seymour, I.; Markiewicz, E.; Alzoghaibi, F.; Benham, A.M.; Edwards, R.; Wenhert, M.; von Zglinicki, T.; Hutchison, C.J. Conserved cysteine residues in the mammalian lamin A tail are essential for cellular responses to ROS generation. Aging Cell. 2011, 10, 1067-1079. [CrossRef] [PubMed] 
157. Angori, S.; Capanni, C.; Faulkner, G.; Bean, C.; Boriani, G.; Lattanzi, G.; Cenni, V. Emery-Dreifuss Muscular Dystrophy-Associated Mutant Forms of Lamin A Recruit the Stress Responsive Protein Ankrd2 into the Nucleus, Affecting the Cellular Response to Oxidative Stress. Cell. Physiol. Biochem. 2017, 42, 169-184. [CrossRef] [PubMed]

158. Coombs, G.S.; Rios-Monterrosa, J.L.; Lai, S.; Dai, Q.; Goll, A.C.; Ketterer, M.R.; Valdes, M.F.; Uche, N.; Benjamin, I.J.; Wallrath, L.L. Modulation of muscle redox and protein aggregation rescues lethality caused by mutant lamins. Redox. Biol. 2021, $48,102196$. [CrossRef] [PubMed]

159. Mocciaro, E.; Runfola, V.; Ghezzi, P.; Pannese, M.; Gabellini, D. DUX4 Role in Normal Physiology and in FSHD Muscular Dystrophy. Cells. 2021, 10, 3322. [CrossRef] [PubMed]

160. Nikolic, A.; Jones, T.I.; Govi, M.; Mele, F.; Maranda, L.; Sera, F.; Ricci, G.; Ruggiero, L.; Vercelli, L.; Portaro, S.; et al. Interpretation of the Epigenetic Signature of Facioscapulohumeral Muscular Dystrophy in Light of Genotype-Phenotype Studies. Int. J. Mol. Sci. 2020, 7, 2635. [CrossRef]

161. Salsi, V.; Magdinier, F.; Tupler, R. Does DNA Methylation Matter in FSHD? Genes 2020, 11, 258. [CrossRef] [PubMed]

162. Karpukhina, A.; Galkin, I.; Ma, Y.; Dib, C.; Zinovkin, R.; Pletjushkina, O.; Chernyak, B.; Popova, E.; Vassetzky, Y. Analysis of genes regulated by DUX4 via oxidative stress reveals potential therapeutic targets for treatment of facioscapulohumeral dystrophy. Redox. Biol. 2021, 43, 102008. [CrossRef]

163. Sasaki-Honda, M.; Jonouchi, T.; Arai, M.; Hotta, A.; Mitsuhashi, S.; Nishino, I. A patient-derived iPSC model revealed oxidative stress increases facioscapulohumeral muscular dystrophy-causative DUX4. Hum. Mol. Genet. 2018, 27, $4024-4035$. [CrossRef] [PubMed]

164. Laird, D.W.; Lampe, P.D. Cellular mechanisms of connexin-based inherited diseases. Trends Cell. Biol. $2022,32,58-69$. [CrossRef] [PubMed]

165. Peracchia, C. Calmodulin-Mediated Regulation of Gap Junction Channels. Int. J. Mol. Sci. 2020, 21, 485. [CrossRef] [PubMed]

166. Xing, L.; Yang, T.; Cui, S.; Chen, G. Connexin Hemichannels in Astrocytes, Role in CNS Disorders. Front. Mol. Neurosci. 2019, 12, 23. [CrossRef]

167. Schalper, K.A.; Sánchez, H.A.; Lee, S.C.; Altenberg, G.A.; Nathanson, M.H.; Sáez, J.C. Connexin 43 hemichannels mediate the $\mathrm{Ca}^{2+}$ influx induced by extracellular alkalinization. Am. J. Physiol. Cell. Physiol. 2010, 299, C1504-C1515. [CrossRef] [PubMed]

168. Fiori, M.C.; Figueroa, V.; Zoghbi, M.E.; Saéz, J.C.; Reuss, L.; Altenberg, G.A. Calcium transport through purified connexin 26 hemichannels. J. Biol. Chem. 2012, 287, 40826-40834. [CrossRef]

169. Vargas, A.A.; Cisterna, B.A.; Saavedra-Leiva, F.; Urrutia, C.; Cea, L.A.; Vielma, A.H.; Gutierrez-Maldonado, S.E.; Martin, A.J.; Pareja-Barrueto, C.; Escalona, Y.; et al. On Biophysical Properties and Sensitivity to Gap Junction Blockers of Connexin 39 Hemichannels Expressed in HeLa Cells. Front. Physiol. 2017, 8, 38. [CrossRef] [PubMed]

170. Laird, D.W.; Penuela, S. Pannexin biology and emerging linkages to cancer. Trends Cancer. 2021, 7, 1119-1131. [CrossRef] [PubMed]

171. Yeung, A.K.; Patil, C.S.; Jackson, M.F. Pannexin-1 in the CNS, Emerging concepts in health and disease. J. Neurochem. 2020, 154, 468-485. [CrossRef]

172. Pham, T.L.; St-Pierre, M.-E.; Ravel-Chapuis, A.; Parks, T.E.C.; Langlois, S.; Penuela, S.; Jasmin, B.J.; Cowan, K.N. Expression of Pannexin 1 and Pannexin 3 during skeletal muscle development, regeneration, and Duchenne muscular dystrophy. J. Cell. Physiol. 2018, 233, 7057-7070. [CrossRef] [PubMed]

173. Michalski, K.; Henze, E.; Nguyen, P.; Lynch, P.; Kawate, T. The weak voltage dependence of pannexin 1 channels can be tuned by N-terminal modifications. J. Gen. Physiol. 2018, 150, 1758-1768. [CrossRef] [PubMed]

174. López, X.; Escamilla, R.; Fernández, P.; Duarte, Y.; González-Nilo, F.; Palacios-Prado, N.; Martinez, A.D.; Sáez, J.C. Stretch-Induced Activation of Pannexin 1 Channels Can Be Prevented by PKA-Dependent Phosphorylation. Int. J. Mol. Sci. 2020, $21,9180$. [CrossRef] [PubMed]

175. López, X.; Palacios-Prado, N.; Güiza, J.; Escamilla, R.; Fernández, P.; Vega, J.L.; Rojas, M.; Marquez-Miranda, V.; Chamorro, E.; Cárdenas, A.M.; et al. A physiologic rise in cytoplasmic calcium ion signal increases pannexin1 channel activity via a C-terminus phosphorylation by CaMKII. Proc. Natl. Acad. Sci. USA 2021, 118, e2108967118. [CrossRef]

176. Maldifassi, M.C.; Momboisse, F.; Guerra, M.J.; Vielma, A.H.; Maripillán, J.; Báez-Matus, X.; Flores-Muñoz, C.; Cádiz, B.; Schmachtenberg, O.; Martínez, A.D.; et al. The interplay between $\alpha 7$ nicotinic acetylcholine receptors, pannexin- 1 channels and P2X7 receptors elicit exocytosis in chromaffin cells. J. Neurochem. 2021, 157, 1789-1808. [PubMed]

177. Sandilos, J.K.; Chiu, Y.H.; Chekeni, F.B.; Armstrong, A.J.; Walk, S.F.; Ravichandran, K.S.; Bayliss, D.A. Pannexin 1, an ATP release channel, is activated by caspase cleavage of its pore-associated C-terminal autoinhibitory region. J. Biol. Chem. 2012, 287, 11303-11311. [CrossRef]

178. Constantin, B.; Cronier, L. Involvement of gap junctional communication in myogenesis. Int. Rev. Cytol. 2000, 196, 1-65.

179. Cisterna, C.B.; Vargas, A.A.; Puebla, C.; Lagos, C.F.; Escamilla, R.; Lagos, C.F.; Matus, M.F.; Vilos, C.; Cea, L.A.; Barnafi, E.; et al. Active acetylcholine receptors prevent the atrophy of skeletal muscles and favor reinnervation. Nat. Commun. 2020, 11, 1073. [CrossRef]

180. Belluardo, N.; Trovato-Salinaro, A.; Mudò, G.; Condorelli, D.F. Expression of the rat connexin 39 (rCx39) gene in myoblasts and myotubes in developing and regenerating skeletal muscles, An in situ hybridization study. Cell Tissue Res. 2005, 320, 299-310. [CrossRef]

181. Araya, R.; Eckardt, D.; Maxeiner, S.; Krüger, O.; Theis, M.; Willecke, K.; Sáez, J.C. Expression of connexins during differentiation and regeneration of skeletal muscle, functional relevance of connexin43. J. Cell. Sci. 2005, 118, 27-37. [CrossRef] 
182. Riquelme, M.A.; Cea, L.C.; Vega, J.L.; Puebla, C.; Vargas, A.A.; Shoji, K.F.; Subiabre, M.; Sáez, J.C. Pannexin channels mediate the acquisition of myogenic commitment in $\mathrm{C} 2 \mathrm{C} 12$ reserve cells promoted by $\mathrm{P} 2$ receptor activation. Front. Cell. Dev. Biol. 2015, 3, 25. [CrossRef]

183. Langlois, S.; Xiang, X.; Young, K.; Cowan, B.J.; Penuela, S.; Cowan, K.N. Pannexin 1 and Pannexin 3 Channels Regulate Skeletal Muscle Myoblast Proliferation and Differentiation. J. Biol. Chem. 2014, 289, 30717-30731. [CrossRef]

184. Lin, J.H.; Lou, N.; Kang, N.; Takano, T.; Hu, F.; Han, X.; Xu, Q.; Lovatt, D.; Torres, A.; Willecke, K.; et al. A central role of connexin 43 in hypoxic preconditioning. J. Neurosci. 2008, 28, 681-695. [CrossRef] [PubMed]

185. Boengler, K.; Dodoni, G.; Rodriguez-Sinovas, A.; Cabestrero, A.; Ruiz-Meana, M.; Gres, P.; Konietzka, I.; Lopez-Iglesias, C.; Garcia-Dorado, D.; Di Lisa, F.; et al. Connexin 43 in cardiomyocyte mitochondria and its increase by ischemic preconditioning. Cardiovasc. Res. 2005, 67, 234-244. [CrossRef]

186. Retamal, M.A.; Cortés, C.J.; Reuss, L.; Bennett, M.V.L.; Sáez, J.C. S-nitrosylation and permeation through connexin 43 hemichannels in astrocytes, induction by oxidant stress and reversal by reducing agents. Proc. Natl. Acad. Sci. USA 2006, 103, 4475-4480. [CrossRef]

187. Lillo, M.A.; Himelman, E.; Shirokova, N.; Xie, L.H.; Fraidenraich, D.; Contreras, J.E. S-nitrosylation of connexin 43 hemichannels elicits cardiac stress-induced arrhythmias in Duchenne muscular dystrophy mice. JCI Insight 2019, 4, e130091. [CrossRef]

188. Shi, W.; Riquelme, M.A.; Gu, S.; Jiang, J.X. Connexin hemichannels mediate glutathione transport and protect lens fiber cells from oxidative stress. J. Cell. Sci. 2018, 131, jcs212506. [CrossRef]

189. Ma, J.W.; Ji, D.D.; Li, Q.Q.; Zhang, T.; Luo, L. Inhibition of connexin 43 attenuates oxidative stress and apoptosis in human umbilical vein endothelial cells. BMC Pulm. Med. 2020, 20, 19. [CrossRef]

190. Zhou, Y.; Gao, L.; Xia, P.; Zhao, J.; Li, W.; Zhou, Y.; Wei, Q.; Wu, Q.; Wu, Q.; Sun, D.; et al. Glycyrrhetinic Acid Protects Renal Tubular Cells against Oxidative Injury via Reciprocal Regulation of JNK-Connexin 43-Thioredoxin 1 Signaling. Front. Pharmacol. 2021, 12, 619567. [CrossRef] [PubMed]

191. Balboa, E.; Saavedra, F.; Cea, L.A.; Ramírez, V.; Escamilla, R.; Vargas, A.; Regueira, R.; Sáez, J.C. Vitamin E blocks connexin hemichannelsand prevents deleterious effects of glucocorticoid treatment on skeletal muscles. Int. J. Mol. Sci. 2020, 21, 4094. [CrossRef]

192. Millay, D.P.; Goonasekera, S.A.; Sargent, M.A.; Maillet, M.; Aronow, B.J.; Molkentin, J.D. Calcium influx is sufficient to induce muscular dystrophy through a TRPC-dependent mechanism. Proc. Natl. Acad. Sci. USA 2009, 106, 19023-19028. [CrossRef]

193. Altamirano, F.; Valladares, D.; Henríquez-Olguín, C.; Casas, M.; López, J.R.; Allen, P.D.; Jaimovich, E. Nifedipine Treatment Reduces Resting Calcium Concentration, Oxidative and Apoptotic Gene Expression, and Improves Muscle Function in Dystrophic mdx Mice. PLoS ONE 2013, 8, e81222. [CrossRef]

194. Himelman, E.; Lillo, M.A.; Nouet, J.; Gonzalez, J.P.; Zhao, Q.; Xie, L.H.; Li, H.; Liu, T.; Wehrens, X.H.; Lampe, P.D.; et al. Prevention of connexin-43 remodeling protects against Duchenne muscular dystrophy cardiomyopathy. J. Clin. Investig. 2020, 130, 1713-1727. [CrossRef]

195. Huang, B.R.; Tsai, C.H.; Chen, C.C.; Way, T.D.; Kao, J.Y.; Liu, Y.S.; Lin, H.Y.; Lai, S.W.; Lu, D.Y. Curcumin Promotes Connexin 43 Degradation and Temozolomide-Induced Apoptosis in Glioblastoma Cells. Am. J. Chin. Med. 2019, 47, 657-674. [CrossRef]

196. Smyth, J.W.; Hong, T.T.; Gao, D.; Vogan, J.M.; Jensen, B.C.; Fong, T.S.; Simpson, P.C.; Stainier, D.Y.; Chi, N.C.; Shaw, R.M. Limited forward trafficking of connexin 43 reduces cell-cell coupling in stressed human and mouse myocardium. J. Clin. Investig. 2010, 120, 266-279. [CrossRef]

197. Vielma, A.Z.; Boric, M.P.; Gonzalez, D.R. Apocynin Treatment Prevents Cardiac Connexin 43 Hemichannels Hyperactivity by Reducing Nitroso-Redox Stress in Mdx Mice. Int. J. Mol. Sci. 2020, 21, 5415. [CrossRef]

198. Cea, L.A.; Fernández, G.; Arias-Bravo, G.; Castillo-Ruiz, M.; Escamilla, R.; Brañes, M.C.; Sáez, J.C. Blockade of Hemichannels Normalizes the Differentiation Fate of Myoblasts and Features of Skeletal Muscles from Dysferlin-Deficient Mice. Int. J. Mol. Sci. 2020, 21, 6025. [CrossRef]

199. Fernández, G.; Arias-Bravo, G.; Bevilacqua, J.A.; Castillo-Ruiz, M.; Caviedes, P.; Sáez, J.C.; Cea, L.A. Myofibers deficient in connexins 43 and 45 expression protect mice from skeletal muscle and systemic dysfunction promoted by a dysferlin mutation. Biochim. Biophys. Acta Mol. Basis Dis. 2020, 1866, 165800. [CrossRef]

200. Yi, C.; Ezan, P.; Fernández, P.; Schmitt, J.; Sáez, J.C.; Giaume, C.; Koulakoff, A. Inhibition of glial hemichannels by boldine treatment reduces neuronal suffering in a murine model of Alzheimer's disease. Glia 2017, 65, 1607-1625. [CrossRef]

201. Lau, Y.S.; Ling, W.C.; Murugan, D.; Mustafa, M.R. Boldine Ameliorates Vascular Oxidative Stress and Endothelial Dysfunction, Therapeutic Implication for Hypertension and Diabetes. J. Cardiovasc. Pharmacol. 2015, 65, 522-531. [CrossRef]

202. Sáez, J.C.; Contreras-Duarte, S.; Labra, V.C.; Santibañez, C.A.; Mellado, L.A.; Inostroza, C.A.; Alvear, T.F.; Retamal, M.A.; Velarde, V.; Orellana, J.A. Interferon- $\gamma$ and high glucose-induced opening of Cx43 hemichannels causes endothelial cell dysfunction and damage. Biochem. Biophys. Acta Mol. Cell. Res. 2020, 1867, 118720. [CrossRef]

203. Andreana, I.; Repellin, M.; Carton, F.; Kryza, D.; Briançon, S.; Chazaud, B.; Mounier, R.; Arpicco, S.; Malatesta, M.; Stella, B.; et al. Nanomedicine for Gene Delivery and Drug Repurposing in the Treatment of Muscular Dystrophies. Pharmaceutics 2021, 13, 278. [CrossRef]

204. Zhang, Y.; Nishiyama, T.; Olson, E.N.; Bassel-Duby, R. CRISPR/Cas correction of muscular dystrophies. Exp. Cell. Res. 2021, 408, 112844. [CrossRef] 
205. Aronson, J.K. Defining 'nutraceuticals', neither nutritious nor pharmaceutical. Br. J. Clin. Pharmacol. 2017, 83, 8-19. [CrossRef] [PubMed]

206. Lançon, A.; Frazzi, R.; Latruffe, N. Anti-Oxidant, Anti-Inflammatory and Anti-Angiogenic Properties of Resveratrol in Ocular Diseases. Molecules 2016, 21, 304. [CrossRef] [PubMed]

207. Truong, V.L.; Jun, M.; Jeong, W.S. Role of resveratrol in regulation of cellular defense systems against oxidative stress. Biofactors 2018, 44, 36-49. [CrossRef]

208. Menzies, K.J.; Singh, K.; Saleem, A.; Hood, D.A. Sirtuin 1-mediated effects of exercise and resveratrol on mitochondrial biogenesis. J. Biol. Chem. 2013, 288, 6968-6979. [CrossRef]

209. Fernandes, T.; Gomes, J.L.P.; Silveira, A.C. Epigenetic regulation of sirtuin 1-induced skeletal muscle mass, exercise and heart disease. J. Physiol. 2017, 595, 6597-6598. [CrossRef]

210. Lagouge, M.; Argmann, C.; Gerhart-Hines, Z.; Meziane, H.; Lerin, C.; Daussin, F.; Messadeq, N.; Milne, J.; Lambert, P.; Elliott, P.; et al. Resveratrol improves mitochondrial function and protects against metabolic disease by activating SIRT1 and PGC-1alpha. Cell 2006, 127, 1109-1122. [CrossRef]

211. Chen, L.L.; Zhang, H.H.; Zheng, J.; Hu, X.; Kong, W.; Hu, D.; Wang, S.X.; Zhang, P. Resveratrol attenuates high-fat diet-induced insulin resistance by influencing skeletal muscle lipid transport and subsarcolemmal mitochondrial $\beta$-oxidation. Metabolism 2011, 60, 1598-1609. [CrossRef] [PubMed]

212. Kuno, A.; Hosoda, R.; Sebori, R.; Hayashi, T.; Sakuragi, H.; Tanabe, M.; Horio, Y. Resveratrol Ameliorates Mitophagy Disturbance and Improves Cardiac Pathophysiology of Dystrophin-deficient mdx Mice. Sci. Rep. 2018, 8, 15555. [CrossRef] [PubMed]

213. Sebori, R.; Kuno, A.; Hosoda, R.; Hayashi, T.; Horio, Y. Resveratrol Decreases Oxidative Stress by Restoring Mitophagy and Improves the Pathophysiology of Dystrophin-Deficient mdx Mice. Oxid. Med. Cell. Longev. 2018, 2018, 9179270. [CrossRef] [PubMed]

214. Woodman, K.G.; Coles, C.A.; Lamandé, S.R.; White, J.D. Resveratrol Promotes Hypertrophy in Wildtype Skeletal Muscle and Reduces Muscle Necrosis and Gene Expression of Inflammatory Markers in Mdx Mice. Molecules 2021, 26, 853. [CrossRef] [PubMed]

215. Chen, K.H.; Cheng, M.L.; Jing, Y.H.; Chiu, D.T.; Shiao, M.S.; Chen, J.K. Resveratrol ameliorates metabolic disorders and muscle wasting in streptozotocin-induced diabetic rats. Am. J. Physiol. Endocrinol. Metab. 2011, 301, E853-E863. [CrossRef] [PubMed]

216. Shadfar, S.; Couch, M.E.; McKinney, K.A.; Weinstein, L.J.; Yin, X.; Rodríguez, J.E.; Guttridge, D.C.; Willis, M. Oral resveratrol therapy inhibits cancer-induced skeletal muscle and cardiac atrophy in vivo. Nutr. Cancer 2011, 63, 749-762. [CrossRef]

217. Sun, L.J.; Sun, Y.N.; Chen, S.J.; Liu, S.; Jiang, G.R. Resveratrol attenuates skeletal muscle atrophy induced by chronic kidney disease via MuRF1 signaling pathway. Biochem. Biophys. Res. Commun. 2017, 487, 83-89. [CrossRef]

218. Bai, C.H.; Alizargar, J.; Peng, C.Y.; Wu, J.P. Combination of exercise training and resveratrol attenuates obese sarcopenia in skeletal muscle atrophy. Chin. J. Physiol. 2020, 63, 101-112. [PubMed]

219. Hori, Y.S.; Kuno, A.; Hosoda, R.; Tanno, M.; Miura, T.; Shimamoto, K.; Horio, Y. Resveratrol ameliorates muscular pathology in the dystrophic mdx mouse, a model for Duchenne muscular dystrophy. J. Pharmacol. Exp. Ther. 2011, 338, 784-794. [CrossRef]

220. Harper, S.A.; Bassler, J.R.; Peramsetty, S.; Yang, Y.; Roberts, L.M.; Drummer, D.; Mankowski, R.T.; Leeuwenburgh, C.; Ricart, K.; Patel, R.P.; et al. Resveratrol and exercise combined to treat functional limitations in late life, A pilot randomized controlled trial. Exp. Gerontol. 2020, 15, 111111. [CrossRef]

221. Kawamura, K.; Fukumura, S.; Nikaido, K.; Tachi, N.; Kozuka, N.; Seino, T.; Hatakeyama, K.; Mori, M.; Ito, Y.M.; Takami, A.; et al Resveratrol improves motor function in patients with muscular dystrophies, an open-label, single-arm, phase IIa study. Sci. Rep. 2020, 10, 20585. [CrossRef]

222. Murillo Ortiz, B.O.; Fuentes Preciado, A.R.; Ramírez Emiliano, J.; Martínez Garza, S.; Ramos Rodríguez, E.; de Alba Macías, L.A. Recovery Of Bone And Muscle Mass In Patients With Chronic Kidney Disease And Iron Overload On Hemodialysis And Taking Combined Supplementation With Curcumin And Resveratrol. Clin. Interv. Aging. 2019, 14, 2055-2062. [CrossRef]

223. Shaito, A.; Posadino, A.M.; Younes, N.; Hasan, H.; Halabi, S.; Alhababi, D.; Al-Mohannadi, A.; Abdel-Rahman, W.M.; Eid, A.H.; Nasrallah, G.K.; et al. Potential Adverse Effects of Resveratrol, A Literature Review. Int. J. Mol. Sci. 2020, 21, 2084. [CrossRef]

224. Cai, H.; Scott, E.; Kholghi, A.; Andreadi, C.; Rufini, A.; Karmokar, A.; Britton, R.G.; Horner-Glister, E.; Greaves, P.; Jawad, D.; et al Cancer chemoprevention, Evidence of a nonlinear dose response for the protective effects of resveratrol in humans and mice. Sci. Transl. Med. 2015, 7, 298ra117. [CrossRef]

225. Mancuso, M.; Orsucci, D.; Calsolaro, V.; Choub, A.; Siciliano, G. Coenzyme Q10 and Neurological Diseases. Pharmaceuticals 2009, 2, 134-149. [CrossRef] [PubMed]

226. Bentinger, M.; Brismar, K.; Dallner, G. The antioxidant role of coenzyme Q. Mitochondrion 2007, 7, S41-S50. [CrossRef]

227. Genova, M.L.; Lenaz, G. New developments on the functions of coenzyme Q in mitochondria. Biofactors 2011, 37, 330-354. [CrossRef] [PubMed]

228. Akbari, A.; Mobini, G.R.; Agah, S.; Morvaridzadeh, M.; Omidi, A.; Potter, E.; Fazelian, S.; Ardehali, S.H.; Daneshzad, E.; Dehghani, S. Coenzyme Q10 supplementation and oxidative stress parameters, a systematic review and meta-analysis of clinical trials. Eur. J. Clin. Pharmacol. 2020, 76, 1483-1499. [CrossRef]

229. Sangsefidi, Z.S.; Yaghoubi, F.; Hajiahmadi, S.; Hosseinzadeh, M. The effect of coenzyme Q10 supplementation on oxidative stress, A systematic review and meta-analysis of randomized controlled clinical trials. Food Sci. Nutr. 2020, 8, 1766-1776. [CrossRef]

230. Mizobuti, D.S.; Fogaça, A.R.; Moraes, F.D.S.R.; Moraes, L.H.R.; Mâncio, R.D.; Hermes, T.D.A.; Macedo, A.B.; Valduga, A.H.; de Lourenço, C.C.; Pereira, E.C.L.; et al. Coenzyme Q10 supplementation acts as antioxidant on dystrophic muscle cells. Cell. Stress Chaperones 2019, 24, 1175-1185. [CrossRef] 
231. Spurney, C.F.; Rocha, C.T.; Henricson, E.; Florence, J.; Mayhew, J.; Gorni, K.; Pasquali, L.; Pestronk, A.; Martin, G.R.; Hu, F.; et al. Cooperative International Neuromuscular Research Group Investigators. CINRG pilot trial of coenzyme Q10 in steroid-treated Duchenne muscular dystrophy. Muscle Nerve 2011, 44, 174-178. [CrossRef]

232. Kotha, R.R.; Luthria, D.L. Curcumin, Biological, Pharmaceutical, Nutraceutical, and Analytical Aspects. Molecules 2019, $24,2930$. [CrossRef] [PubMed]

233. Meng, B.; Li, J.; Cao, H. Antioxidant and anti-inflammatory activities of curcumin on diabetes mellitus and its complications. Curr. Pharm. Des. 2013, 19, 2101-2113. [PubMed]

234. Pan, Y.; Zhang, X.; Wang, Y.; Cai, L.; Ren, L.; Tang, L.; Wang, J.; Zhao, Y.; Wang, Y.; Liu, Q.; et al. Targeting JNK by a new curcumin analog to inhibit NF-kB-mediated expression of cell adhesion molecules attenuates renal macrophage infiltration and injury in diabetic mice. PLoS ONE 2013, 8, e79084. [CrossRef] [PubMed]

235. Durham, W.J.; Arbogast, S.; Gerken, E.; Li, Y.P.; Reid, M.B. Progressive nuclear factor-k B activation resistant to inhibition by contraction and curcumin in mdx mice. Muscle Nerve 2006, 34, 298-303. [CrossRef] [PubMed]

236. Pan, Y.; Chen, C.; Shen, Y.; Zhu, C.H.; Wang, G.; Wang, X.C.; Chen, H.Q.; Zhu, M.S. Curcumin alleviates dystrophic muscle pathology in mdx mice. Mol. Cells 2008, 25, 531-537. [PubMed]

237. Grilc, N.K.; Sova, M.; Kristl, J. Drug Delivery Strategies for Curcumin and Other Natural Nrf2 Modulators of Oxidative Stress-Related Diseases. Pharmaceutics 2021, 13, 2137. [CrossRef] [PubMed] 